\title{
Genesis of the columnar joints from welded tuff in Mount Mudeung National Geopark, Republic of Korea
}

\author{
Chungwan Lim', Min Huh', Keewook Yi ${ }^{2}$ and Changyeol Lee ${ }^{1 *}$
}

\begin{abstract}
Mount Mudeung National Geopark (MMNG), Gwangju, Republic of Korea (1187 masl), is known for its huge, broad occurrences of columnar jointed colonnades in the Cretaceous Mudeungsan Tuff. To understand the genesis of columnar joints infilling a volcanic vent, integrated geochemical and geophysical studies were conducted. Most colonnades in the Geopark are located in regions higher than 700 masl and show elevation-dependent variations in the mean face width of the columns. These mean widths are approximately 1.7, 1.3, 2.9, and $1.2 \mathrm{~m}$ for the summit (>1100 masl), upper (950-1100 masl), lower (850-950 masl), and lowest (700-850 masl) colonnades, respectively. This variation implies that columnar jointing resulted from discontinuous tuff depositions on relatively planar ground, which is associated with caldera structures and landslides from the emptied caldera rim. Geochemical analyses of major, minor, and trace elements show that the andesitic-dacitic Mudeungsan Tuff resulted from the arc magmatism associated with subduction of the Izanagi Plate and involved crustal components. Few geochemical variations of the Mudeungsan Tuff indicate that tuff originated from a single magma chamber. U-Pb age dating indicates that the Mudeungsan Tuff was deposited at $\sim 85 \mathrm{Ma}$ except for the Chotdae-bong colonnades, which were dated to $\sim 87 \mathrm{Ma}$. However, a scaling analysis of the elevation-dependent variations of face widths and simplified numerical model calculations indicate that the variation in face widths with elevation indicates the sequential emplacement, cooling, and compaction of separate welded tuffs. Thus, the welded tuffs of MMNG can be thought to be formed by three discontinuous large explosive eruptions with periods of repose after each eruption. These tuffs include 1) the highest-elevation columnar joints of colonnades in the summit area (>1100 m), corresponding to the lower colonnades of the third tuff; 2) the intermediate-elevation columnar joints of colonnades, corresponding to the upper (950-1100 m) and lower (850-950 m) colonnades of the second tuff; and 3) the lowest columnar joints of colonnades (700-850 masl), corresponding to the upper colonnades of the first tuff.
\end{abstract}

Keywords: Mt. Mudeung; Columnar joint; Colonnade; Welded tuff; Arc volcano; Caldera

\section{Background}

Located in southwestern Korea, Mt. Mudeung (1187 masl) in the Mount Mudeung National Geopark (MMNG) is widely known for the columnar joints of colonnades, which are observed mostly at elevations exceeding 700 masl. The columnar joints of the Seoseok-dae, Ipseok-dae, and Gwangseok-dae colonnades are especially popular among tourists because their columnar joints are massive and prominent (Fig. 1). The columnar joints that developed in

\footnotetext{
* Correspondence: changyeol.lee@gmail.com

${ }^{1}$ Faculty of Earth and Environmental Sciences, Chonnam National University, Gwangju 500-757, Republic of Korea

Full list of author information is available at the end of the article
}

the Mudeungsan Tuff in MMNG are distinguished from other Korean columnar joints in terms of age and size as follows: 1) the columnar joints developed from the Mudeungsan Tuff in the Cretaceous, whereas most of the columnar joints in Korean rocks developed in Quaternary emplacements of basaltic lava (e.g., columnar joints of basaltic colonnades at Daepo-dong and Seoguipo on Jeju Island and those at Daljeon-ri in Gyeongbuk Province) (Koh et al., 2005); and 2) the face widths of the colonnades at Mt. Mudeung range from 1 to $9 \mathrm{~m}$, the largest in Korea, whereas those of basaltic colonnades are only dozens of centimeters. Therefore, the petrological and

\section{它 Springer}




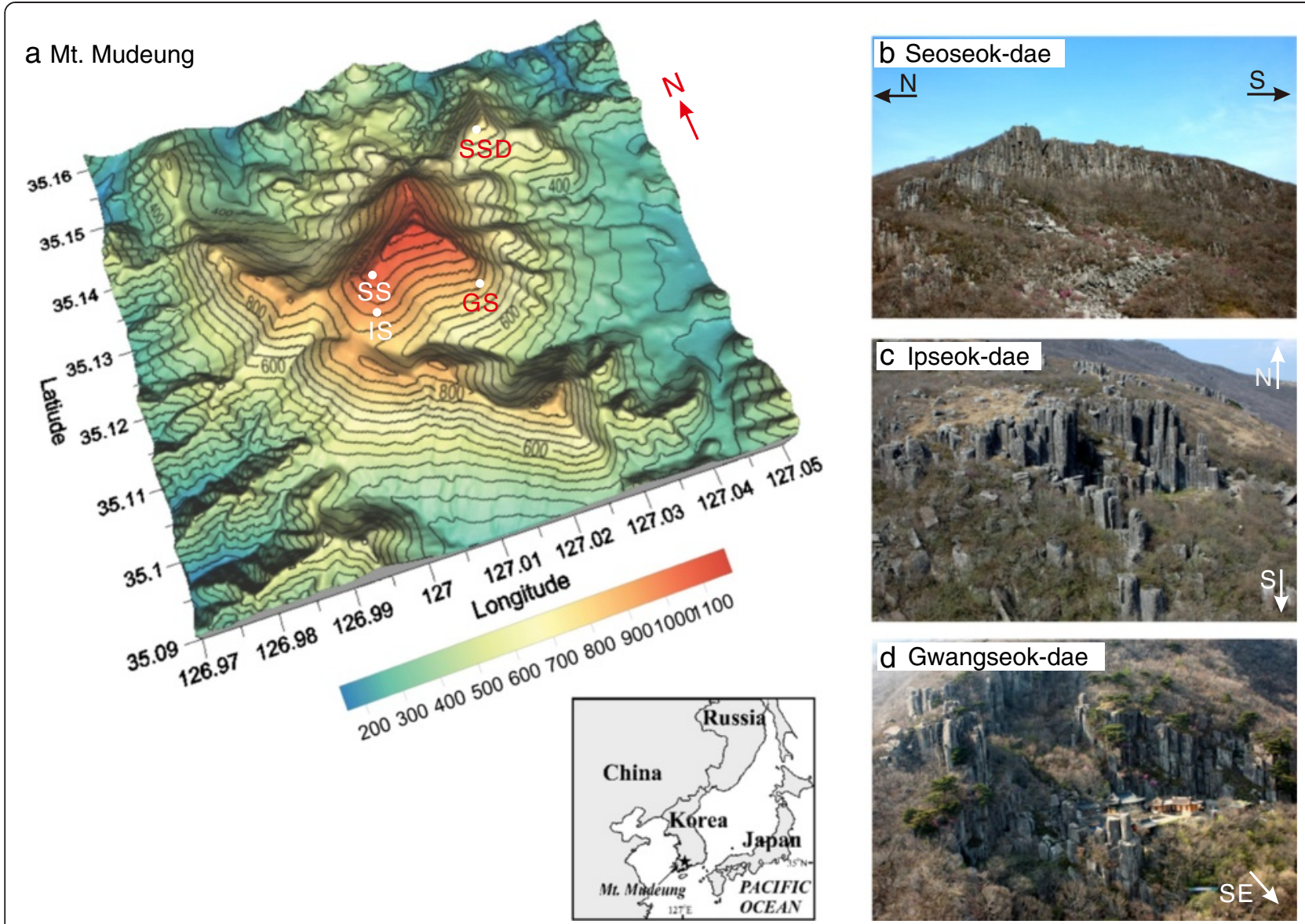

Fig. 1 Three-dimensional topographic map of Mt. Mudeung showing the locations of well-known columnar joints of colonnades. Mt. Mudeung is located at eastern Gwangju. a Contour map with a contour interval of 50 m. SS, IS, GS, and SSD correspond to the Seoseok-dae, Ipseok-dae, Gwangseok-dae, and Sinseon-dae colonnades, respectively. The peak of Mt. Mudeung (1187 masl) is called the Cheonwang-bong. b-d Aerial photographs of the Seoseok-dae, Ipseok-dae, and Gwangseok-dae colonnades, respectively. (Aerial photo courtesy of the Gwangju municipal government)

morphological characteristics of the Mudeungsan Tuff have attracted geological attention for decades.

Most previous research has been conducted in classical petrology (lithology) and geomorphology, and is published mostly in Korean (e.g., Ahn, 2010; Kim et al., 1993; Kim et al., 2002). Consequently, scientific studies focusing on the Mudeungsan tuff are not well known worldwide, and many questions, including the emplacement age and morphology of the Mudeungsan Tuff, remain unanswered. K-Ar dating of the intruded rhyolite (to dacite) is $75.98 \pm 3.35$ and $76.44 \pm 1.09 \mathrm{Ma}$ (Won et al., 1990), so the Mudeungsan Tuff, and the generation of the colonnades should be older than $76 \mathrm{Ma}$. Other studies (e.g., Kim et al., 2002) have constrained the age of the volcanic tuff of Mt. Mudeung from approximately 85 to $79 \mathrm{Ma}$. Although Ahn (2010) analyzed some dacitic rocks collected near the summit of Mt. Mudeung and reported a whole-rock age of $48.1 \pm 1.7 \mathrm{Ma}$, this age may not represent the absolute ages of all of the Mudeungsan Tuff in Mt. Mudeung. For that reason, further research was undertaken to address the genesis of the columnar joints of colonnades, which will lead to better understanding the formation of the Mudeungsan Tuff in MMNG.

This study explores the genesis and subsequent formation of columnar jointing of colonnades in the Mudeungsan Tuff, MMNG. We first estimated the distribution of the Mudeungsan Tuff in MMNG by conducting a series of field campaigns that included measurements of morphological data (e.g., face widths) and rock sampling. Geochemical and chronological analyses were then conducted to assess the volcanic history in MMNG. In addition, we conducted a scaling analysis and numerical models to evaluate the formational history of columnar jointing of the colonnades developed in the Mudeungsan Tuff.

\section{Geologic setting}

\section{Geological background}

Mount Mudeung National Geopark (MMNG) consists of a variety of igneous and metamorphic rocks that span from the Precambrian to the Cretaceous (Fig. 2). Igneous activity 


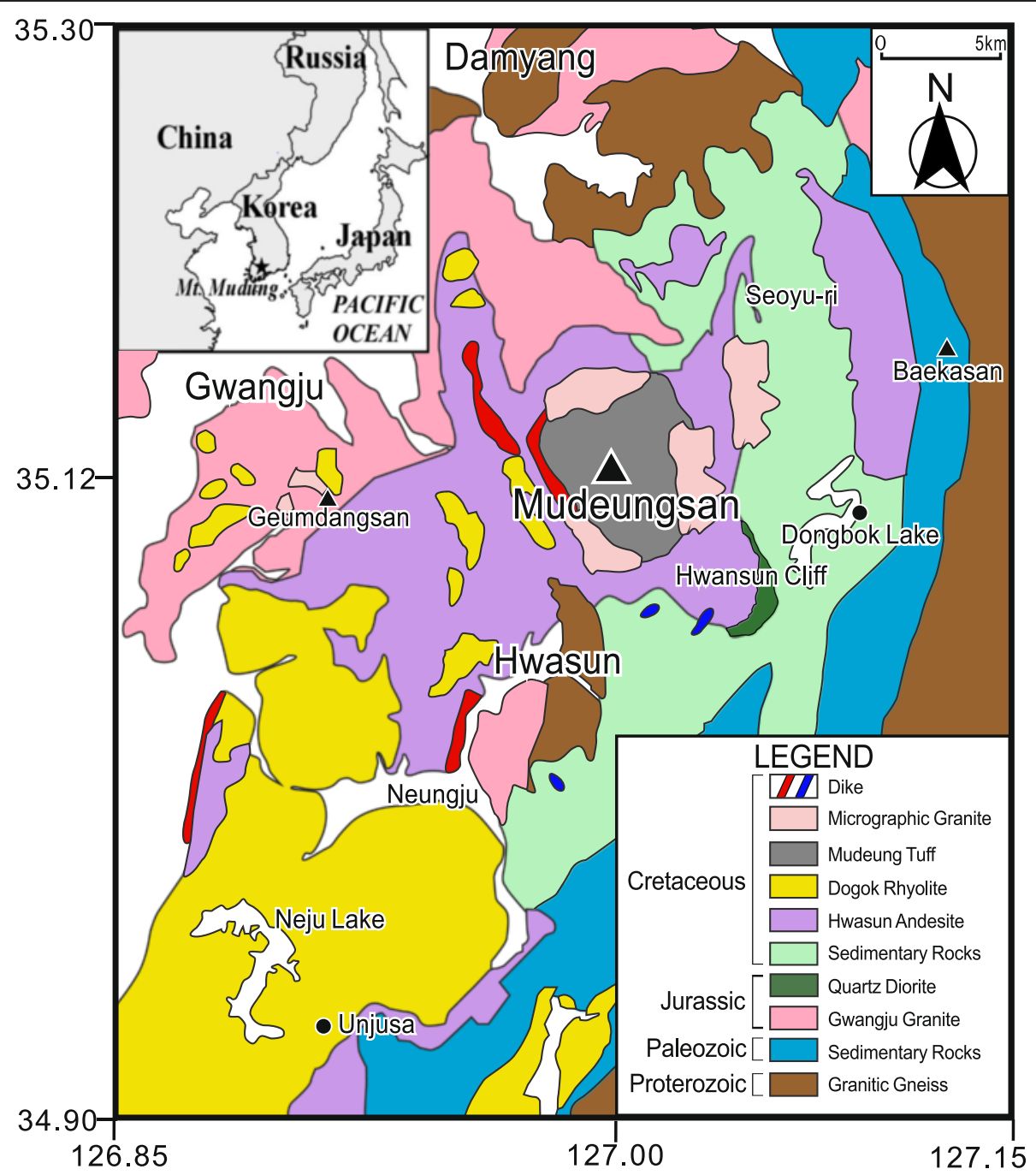

Fig. 2 Geological map of Mount Mudeung National Geopark (MMNG), modified from the geological map of the Korean Institute of Geosciences and Mineral Resources (KIGAM) and the 1:50,000 topographic map of the National Geographic Information Institute of Korea

in the Mt. Mudeung area began in the Precambrian with the intrusion of granite, currently granitic gneiss, and continued with the intrusion of micrographic granite (Kim and Lee, 1988). In the Middle Jurassic, although igneous activities were associated with subductionrelated arc magmatism throughout southern Korea (Sagong et al., 2005), only a small intrusion of Jurassic quartz diorite was emplaced at that time in the Mt. Mudeung area. Large-scale volcanic activity began in the Cretaceous with the lava flows of andesite, dacite, and rhyolite. In the Middle Cretaceous, large volcanoes erupted, thereby forming tuff at Mt. Mudeung. The exposure of Mudeungsan Tuff at the summit of Mt. Mudeung (Cheonwang-bong) and at Mt. Anyang were welded crystal tuff with dacitic composition and were generated from cogenetic calc-alkaline magma in the volcanic arc environment. The magma beneath the summit of Mt.
Mudeung was evolved from the magma beneath Mt. Anyang due to fractional crystallization dominated by plagioclase (Jung et al., 2014). In the Late Cretaceous, micrographic granite and alkali feldspar granite were intruded into the Mudeungsan Tuff. Then, intermediate-acid dyke rocks intruded along the ruptured area (Fig. 2). The Cretaceous magmatisms in the Mt. Mudeung area are thought to be related to the contraction of a magma chamber (Cha and Yun, 1988). Quantitative chronological ages have not been reported except for a single K/Ar age $(48.1 \pm 1.7 \mathrm{Ma})$ of the Mudeungsan Tuff located at the summit area of Mt. Mudeung (Ahn, 2010).

\section{Petrographic background}

The intact granitic gneiss forming the base of Mt. Mudeung and the amphibole-biotite granodiorite of the upper strata of the metamorphic Pyeongan system in the 
Paleozoic sedimentary rocks are observed at the western foot of Mt. Mudeung and in the southern Hwasun region as small-scale intrusions. Some fine to medium-grained euhedral amphibole crystals have also been observed (Kim and Lee, 1988). Quartz, plagioclase, biotite, and amphibole are major minerals; zircon, apatite, and spinel and other opaque minerals occur in minor amounts (Kim and Lee, 1988).

The micrographic granite is red or light red in color and was disturbed by intrusions therefore it predates other rocks. This granite includes quartz, orthoclase, plagioclase, and biotite as major minerals and amphibole, magnetite, apatite, and zircon as minor minerals. Quartz is intergrown with orthoclase that has developed the micrographic texture, and accompanying biotite has been chloritized by subsequent metamorphosis. The magnetite is arranged along cleavage (Kim et al., 2002). Both acidic and intermediate dykes are observed, but the latter are dominant. The former includes quartz-veins, felsite, and pegmatites, and the latter includes porphyritic andesite and massive andesite (Kim et al., 2002).

Quartz diorite exists in southeastern Mt. Mudeung. The periphery is dark gray or midnight blue, as a result of mafic minerals in the rock, whereas the center of the diorite is brighter and pinkish gray or gray. Plagioclase, pyroxene, hypersthene, biotite, quartz, and magnetite are major phases, and epidote and chlorite are minor phases (Kim et al., 2002).

The Hwasun andesite consists of andesitic tuff and lava, as well as intrusive rocks. The andesitic tuff, a lapilli (coarse) tuff, contains light-green rock fragments $(5-10 \mathrm{~mm})$ and purplish brown pumice. The andesitic tuff consists of multiple tuff layers, implying multiple eruptions. They are normally dark green or dark gray, but they are brown or reddish brown under weathered conditions. Only andesitic tuffs have phenocrysts, amygdaloidal structures, and slight flow structures. Amygdaloidal structures are elliptic and amygdales are composed of calcite, chlorite, and chalcedony. Most phenocrysts are plagioclase. Some other colored minerals are observed. The Hwasun andesite contains plagioclase, hyaline, and chloritized colored minerals, and microcrystalline crystals are spread on the hyaline base (Kim et al., 2002).

The rose pink Dogok rhyolite retains a well-developed flow structure. It covers or intrudes the Hwasun andesite, forming a nonconformity. Its flow structure usually consists of alternating red and light-colored layers, which range in thickness from 2 to $5 \mathrm{~mm}$. The rhyolite is composed primarily of plagioclase and biotite, with minor amounts of magnetite and rutile. The red portions of the flow structure are cryptocrystalline or hyaline, and the white portions are composed of microcrystalline quartz. Phenocrysts consist of mostly plagioclase but quartz and amphibole may also be present. The rock also includes andesite xenoliths. In addition, plagioclase phenocrysts are semi-transparent light-gray and range in size from 1 to $5 \mathrm{~mm}$ (Kim et al., 2002).

The Mudeungsan Tuff (quartz-bearing andesitic-dacitic tuff) is dark gray and is classified as porphyroblastic and fabric-forming tuff; it intruded into quartz porphyry and micrographic granite, and it developed flow structure and numerous columnar joints. Phenocrysts are mostly plagioclase, but they contain quartz and amphibole (and even andesite xenolith) in some cases. Plagioclase phenocrysts are semi-transparent light-gray, and their size ranges from $1-2 \mathrm{~mm}$ up to $5 \mathrm{~mm}$. Several welded structures are observed in the hyaline base; this suggests the possibility that a part of the Mudeungsan Tuff may be formed by welded tuff (Kim et al., 2002).

\section{Methods}

Mount Mudeung National Geopark (MMNG) is mostly covered by quartz-bearing andesitic-dacitic tuff. In total, 24 rock samples for major element analyses, 9 rock samples for trace element analyses, and 46 rock samples for U-Pb zircon dating were collected from the four locations, the Seoseok-dae, Ipseok-dae, Gwangseok-dae, and Chotdaebong colonnades (Tables 1 and 2 and Additional file 1: Table S1). Thin sections were prepared. The section thicknesses ranged from $30-50 \mu \mathrm{m}$ when mounted on standard microscope slides for visualization in different planes of focus. Micrographic images were obtained using transmitted light microscopy at $\times 100$ or $\times 200$ magnification, and the samples were photographed. Selected minerals were observed using a petrographic microscope with crosspolarized light and a gypsum plate.

Mineral compositions of plagioclase crystals were analyzed using an electron probe X-ray microanalyzer (EPMA; Model JXA-8900R, JEOL) at Seoul National University, with an accelerating voltage of $15 \mathrm{kV}$, a current of $10 \mathrm{nA}$, and a beam size of $10 \mu \mathrm{m}$. Analytical errors were mostly less than $2 \%$. The data were acquired and reduced using the $\mathrm{ZAF}$ ( $\mathrm{Z}$, influence of atomic number; A, X-ray absorption; and $\mathrm{F}$, secondary fluorescence effects) calculation for matrix corrections. EPMA analysis of plagioclases confirmed that andesine components as labradorite were more calcic and prone to alteration. Plagioclase is generally considered to be andesine because it has a reported chemical composition of An 28.5-44.5 (Kim et al., 2002).

Major element compositions were determined using Xray fluorescence spectrometry (XRF; Shimadzu XRF-1700) of fused glass beads at the National Center for InterUniversity Research Facilities (NCIRF), Seoul National University. An inductively coupled plasma mass spectrometry (ICP-MS; Perkin-Elmer Elan 6100) at Seoul National University was used to determine minor and trace elements from whole-rock of welded tuff. Trace 
Table 1 Major elemental analyses of the four colonnades from Mt. Mudeung

\begin{tabular}{|c|c|c|c|c|c|c|c|c|}
\hline Sample & Ipseok-dae-001 & Ipseok-dae-002 & Ipseok-dae-003 & Ipseok-dae-004 & Ipseok-dae-005 & Ipseok-dae-006 & Ipseok-dae-007 & Ipseok-dae-008 \\
\hline $\mathrm{SiO}_{2}$ & 58.75 & 63.02 & 62.74 & 61.72 & 62.31 & 62.75 & 58.02 & 62.28 \\
\hline $\mathrm{TiO}_{2}$ & 0.54 & 0.53 & 0.50 & 0.51 & 0.50 & 0.54 & 0.50 & 0.50 \\
\hline $\mathrm{Al}_{2} \mathrm{O}_{3}$ & 20.06 & 17.66 & 18.08 & 18.00 & 17.38 & 16.95 & 20.59 & 18.42 \\
\hline $\mathrm{Fe}_{2} \mathrm{O}_{3}$ & 1.07 & 1.35 & 1.23 & 1.10 & 1.45 & 1.00 & 1.55 & 1.46 \\
\hline $\mathrm{FeO}$ & 4.78 & 2.67 & 4.29 & 4.18 & 3.42 & 3.01 & 4.60 & 2.97 \\
\hline $\mathrm{MnO}$ & 0.00 & 0.00 & 0.01 & 0.01 & 0.05 & 0.03 & 0.00 & 0.00 \\
\hline $\mathrm{MgO}$ & 0.70 & 1.71 & -0.28 & 0.71 & 1.70 & 1.91 & 0.76 & 1.36 \\
\hline $\mathrm{CaO}$ & 8.24 & 4.83 & 5.21 & 6.07 & 5.47 & 5.42 & 8.99 & 5.49 \\
\hline $\mathrm{Na}_{2} \mathrm{O}$ & 4.81 & 6.26 & 6.01 & 5.94 & 5.83 & 6.41 & 4.43 & 5.82 \\
\hline $\mathrm{K}_{2} \mathrm{O}$ & 0.35 & 0.75 & 0.70 & 0.58 & 0.65 & 0.70 & 0.32 & 0.64 \\
\hline $\mathrm{P}_{2} \mathrm{O}_{5}$ & 0.00 & 0.02 & 0.00 & 0.00 & 0.00 & 0.07 & 0.00 & 0.03 \\
\hline Total & 99.30 & 98.79 & 98.50 & 98.82 & 98.77 & 98.79 & 99.76 & 98.96 \\
\hline Sample & Seosuk-dae-011 & Seosuk-dae-012 & Seosuk-dae-013 & Seosuk-dae-014 & Seosuk-dae-015 & Seosuk-dae-016 & Seosuk-dae-017 & Seosuk-dae-018 \\
\hline $\mathrm{SiO}_{2}$ & 63.20 & 64.62 & 63.19 & 66.24 & 64.22 & 60.66 & 63.25 & 62.13 \\
\hline $\mathrm{TiO}_{2}$ & 0.50 & 0.52 & 0.50 & 0.50 & 0.51 & 0.52 & 0.51 & 0.51 \\
\hline $\mathrm{Al}_{2} \mathrm{O}_{3}$ & 16.26 & 16.06 & 16.92 & 14.52 & 16.74 & 18.72 & 17.09 & 19.65 \\
\hline $\mathrm{Fe}_{2} \mathrm{O}_{3}$ & 1.61 & 1.17 & 1.47 & 1.59 & 1.49 & 0.92 & 0.64 & 1.51 \\
\hline $\mathrm{FeO}$ & 3.33 & 4.28 & 3.39 & 2.28 & 3.57 & 4.13 & 3.26 & 2.28 \\
\hline $\mathrm{MnO}$ & 0.00 & 0.01 & 0.00 & 0.00 & 0.00 & 0.01 & 0.01 & 0.02 \\
\hline $\mathrm{MgO}$ & 2.72 & 1.71 & 1.74 & 0.72 & 0.55 & 1.77 & 2.59 & 0.92 \\
\hline $\mathrm{CaO}$ & 4.89 & 3.92 & 5.01 & 6.92 & 4.75 & 7.08 & 4.93 & 5.81 \\
\hline $\mathrm{Na}_{2} \mathrm{O}$ & 6.37 & 6.74 & 6.38 & 6.01 & 6.39 & 5.40 & 6.33 & 6.03 \\
\hline $\mathrm{K}_{2} \mathrm{O}$ & 0.73 & 0.78 & 0.65 & 0.77 & 0.69 & 0.39 & 0.67 & 0.60 \\
\hline $\mathrm{P}_{2} \mathrm{O}_{5}$ & 0.04 & 0.03 & 0.08 & 0.06 & 0.01 & 0.00 & 0.06 & 0.03 \\
\hline Total & 99.64 & 99.84 & 99.34 & 99.61 & 98.92 & 99.59 & 99.33 & 99.48 \\
\hline Sample & Gwangseok-dae-021 & Gwangseok-dae-022 & Gwangseok-dae-023 & Gwangseok-dae-024 & Gwangseok-dae-025 & Gwangseok-dae-026 & Gwangseok-dae-027 & Gwangseok-dae-028 \\
\hline $\mathrm{SiO}_{2}$ & 61.86 & 60.12 & 61.94 & 62.05 & 62.29 & 62.96 & 63.40 & 61.91 \\
\hline $\mathrm{TiO}_{2}$ & 0.51 & 0.50 & 0.52 & 0.51 & 0.51 & 0.51 & 0.52 & 0.54 \\
\hline $\mathrm{Al}_{2} \mathrm{O}_{3}$ & 16.35 & 17.49 & 15.51 & 16.36 & 16.22 & 15.56 & 15.28 & 15.91 \\
\hline $\mathrm{Fe}_{2} \mathrm{O}_{3}$ & 1.75 & 1.83 & 2.35 & 1.31 & 1.35 & 1.70 & 1.48 & 1.54 \\
\hline $\mathrm{FeO}$ & 4.28 & 4.52 & 3.26 & 4.31 & 4.29 & 3.32 & 4.25 & 4.78 \\
\hline $\mathrm{MnO}$ & 0.00 & 0.02 & 0.02 & 0.02 & 0.00 & 0.02 & 0.01 & 0.00 \\
\hline $\mathrm{MgO}$ & 1.65 & 1.87 & 3.20 & 1.71 & 1.70 & 4.01 & 2.73 & 2.70 \\
\hline
\end{tabular}


Table 1 Major elemental analyses of the four colonnades from Mt. Mudeung (Continued)

\begin{tabular}{|c|c|c|c|c|c|c|c|c|}
\hline $\mathrm{CaO}$ & 5.78 & 6.82 & 5.92 & 5.54 & 5.38 & 4.85 & 4.61 & 5.38 \\
\hline $\mathrm{Na}_{2} \mathrm{O}$ & 6.01 & 5.30 & 5.92 & 6.11 & 6.19 & 6.37 & 6.59 & 6.06 \\
\hline $\mathrm{K}_{2} \mathrm{O}$ & 0.48 & 0.44 & 0.50 & 0.47 & 0.51 & 0.60 & 0.43 & 0.45 \\
\hline $\mathrm{P}_{2} \mathrm{O}_{5}$ & 0.04 & 0.00 & 0.02 & 0.02 & 0.00 & 0.05 & 0.03 & 0.00 \\
\hline Total & 98.72 & 98.92 & 99.15 & 98.38 & 98.45 & 99.96 & 99.32 & 99.26 \\
\hline Sample & Chotdae-bong-031 & Chotdae-bong-032 & Chotdae-bong-033 & Chotdae-bong-034 & Chotdae-bong-035 & Chotdae-bong-036 & Chotdae-bong-037 & Chotdae-bong-038 \\
\hline $\mathrm{SiO}_{2}$ & 62.73 & 60.57 & 58.15 & 63.25 & 60.71 & 63.13 & 62.36 & 64.27 \\
\hline $\mathrm{TiO}_{2}$ & 0.50 & 0.50 & 0.55 & 0.50 & 0.57 & 0.50 & 0.50 & 0.52 \\
\hline $\mathrm{Al}_{2} \mathrm{O}_{3}$ & 15.88 & 18.03 & 18.49 & 15.70 & 17.91 & 15.38 & 16.53 & 15.29 \\
\hline $\mathrm{Fe}_{2} \mathrm{O}_{3}$ & 1.71 & 1.85 & 2.05 & 1.50 & 1.10 & 1.87 & 1.67 & 1.58 \\
\hline $\mathrm{FeO}$ & 4.31 & 2.22 & 4.30 & 4.28 & 3.27 & 4.78 & 4.57 & 4.00 \\
\hline $\mathrm{MnO}$ & 0.00 & 0.01 & 0.00 & 0.00 & 0.00 & 0.01 & 0.00 & 0.01 \\
\hline $\mathrm{MgO}$ & 1.73 & 2.20 & 2.01 & 2.34 & 2.14 & 1.71 & 1.70 & 1.71 \\
\hline $\mathrm{CaO}$ & 5.00 & 7.24 & 8.90 & 5.04 & 7.18 & 4.86 & 5.56 & 4.25 \\
\hline $\mathrm{Na}_{2} \mathrm{O}$ & 6.15 & 5.10 & 4.24 & 6.32 & 5.28 & 6.29 & 6.19 & 6.67 \\
\hline $\mathrm{K}_{2} \mathrm{O}$ & 0.74 & 0.44 & 0.30 & 0.72 & 0.45 & 0.70 & 0.52 & 0.82 \\
\hline $\mathrm{P}_{2} \mathrm{O}_{5}$ & 0.04 & 0.00 & 0.02 & 0.07 & 0.09 & 0.06 & 0.00 & 0.03 \\
\hline Total & 98.79 & 98.16 & 99.01 & 99.71 & 98.69 & 99.28 & 99.60 & 99.15 \\
\hline
\end{tabular}


Table 2 The concentration of trace elements for the colonnades in the Mudeungsan Tuff (ppm)

\begin{tabular}{|c|c|c|c|c|c|c|c|c|c|}
\hline \multirow{2}{*}{$\begin{array}{l}\text { Sample } \\
\text { Name }\end{array}$} & \multicolumn{3}{|c|}{ Ipseok-dae } & \multicolumn{3}{|c|}{ Seosuk-dae } & \multicolumn{2}{|c|}{ Gwangseok-dae } & \multirow{3}{*}{$\begin{array}{l}\text { Chotdae-bong } \\
032 \\
(980 \mathrm{~m})\end{array}$} \\
\hline & 001 & 003 & 007 & 011 & 015 & 018 & 021 & 023 & \\
\hline Elevation & $(938 \mathrm{~m})$ & (943 m) & $(950 \mathrm{~m})$ & (982 m) & $(1006 \mathrm{~m})$ & $(1030 \mathrm{~m})$ & $(922 \mathrm{~m})$ & $(930 \mathrm{~m})$ & \\
\hline $\mathrm{La}$ & 34.6 & 38.3 & 36.8 & 39.5 & 44.7 & 45.2 & 41.6 & 38.7 & 41.4 \\
\hline $\mathrm{Ce}$ & 68.6 & 70.5 & 70.1 & 74.3 & 78.7 & 81.2 & 73.3 & 84.2 & 77.1 \\
\hline $\operatorname{Pr}$ & 7.14 & 8.51 & 8.27 & 6.53 & 7.24 & 7.18 & 7.56 & 7.17 & 6.42 \\
\hline $\mathrm{Nd}$ & 27.8 & 30.7 & 34.5 & 28.5 & 34.9 & 37.4 & 31.4 & 31.8 & 29.8 \\
\hline Sm & 5.34 & 5.72 & 5.68 & 5.97 & 6.84 & 6.65 & 5.56 & 5.35 & 5.46 \\
\hline $\mathrm{Eu}$ & 1.30 & 1.36 & 1.42 & 1.25 & 1.47 & 1.49 & 1.45 & 1.41 & 1.27 \\
\hline $\mathrm{Gd}$ & 4.65 & 4.21 & 3.84 & 4.06 & 4.53 & 4.55 & 4.07 & 4.49 & 4.08 \\
\hline Dy & 4.34 & 4.07 & 3.88 & 4.52 & 4.28 & 3.58 & 3.75 & 3.77 & 3.79 \\
\hline Ho & 0.74 & 0.72 & 0.72 & 0.81 & 0.75 & 0.73 & 0.92 & 0.86 & 0.84 \\
\hline Er & 2.03 & 2.25 & 2.46 & 2.44 & 2.43 & 2.53 & 2.43 & 2.32 & 2.19 \\
\hline $\mathrm{Yb}$ & 2.09 & 2.21 & 2.35 & 2.12 & 2.23 & 2.26 & 2.04 & 1.98 & 2.11 \\
\hline Lu & 0.31 & 0.33 & 0.29 & 0.34 & 0.34 & 0.34 & 0.32 & 0.36 & 0.31 \\
\hline SC & 13.9 & 13.6 & 12.5 & 11.4 & 12.9 & 14.2 & 11.3 & 10.9 & 8.34 \\
\hline $\mathrm{Yb}$ & 21.3 & 21.3 & 21.3 & 23.1 & 23.1 & 23.1 & 19.2 & 20.6 & 20.4 \\
\hline $\mathrm{Cu}$ & 26.2 & 20.5 & 18.1 & 17.1 & 15.6 & 22.3 & 13.5 & 15.6 & 12.9 \\
\hline $\mathrm{Cr}$ & 7.54 & 6.25 & 5.96 & 4.65 & 4.54 & 3.57 & 6.69 & 7.32 & 2.41 \\
\hline $\mathrm{Ni}$ & 8.57 & 5.41 & 4.65 & 7.21 & 4.11 & 5.31 & 4.75 & 4.65 & 3.02 \\
\hline $\mathrm{Zn}$ & 116 & 122 & 128 & 139 & 122 & 118 & 120 & 109 & 97.2 \\
\hline $\mathrm{Ba}$ & 688 & 987 & 937 & 792 & 877 & 907 & 987 & 943 & 854 \\
\hline Co & 9.72 & 10.7 & 11.5 & 13.2 & 11.5 & 10.3 & 11.2 & 10.9 & 6.74 \\
\hline $\mathrm{Rb}$ & 105 & 126 & 134 & 116 & 102 & 111 & 119 & 108 & 141 \\
\hline $\mathrm{Sr}$ & 397 & 358 & 306 & 387 & 423 & 431 & 441 & 502 & 334 \\
\hline $\mathrm{Zr}$ & 97.1 & 78.5 & 66.3 & 64.7 & 57.3 & 51.9 & 55.5 & 41.7 & 96.3 \\
\hline
\end{tabular}

elements were normalized to an average N-type MORB (Gill, 1981; Pearce, 1982).

Zircons from the Mudeungsan Tuff samples were dated using $\mathrm{U} / \mathrm{Pb}$ and a sensitive high-resolution ion microprobe (SHRIMP). Zircons were purified using standard crushing, magnetic separation, and water-based panning techniques. Handpicked zircons were mounted in epoxy with zircon standards SL13 $(\mathrm{U}=238 \mathrm{ppm})$ and FC1 $\left({ }^{206} \mathrm{~Pb}^{*} /{ }^{238} \mathrm{U}=0.1859\right)$ and were then polished to expose cross-sectional areas for analysis. Individual crystals were photographed using an optical microscope, and internal zonation was documented by backscattered electron microscopy and cathodoluminescence (CL) imaging using a JEOL JSM_6610LV scanning electron microscope (SEM). The zircons were analyzed for $\mathrm{Pb}-\mathrm{Th}-\mathrm{U}$ isotopes using the SHRIMP IIe/MC ion microprobe installed at the Korea Basic Science Institute. Conditions and data acquisition procedures were similar to those described by Williams et al. (2009). Corrections for much larger interelement fractionations were made by reference to the FC1 standard using a power-law relationship between $\mathrm{Pb}^{+} / \mathrm{U}^{+}$ and $\mathrm{UO}^{+} / \mathrm{U}^{+}$. Ages were calculated using the constants recommended by the International Union of Geosciences (IUGS) Subcommission on Geochronology (Steiger and Jäger, 1977).

\section{Results}

\section{Field observations}

Field campaigns confirmed the distribution of columnar joints of colonnades in Mount Mudeung National Geopark (MMNG). Columnar joints of colonnades are present in 1) the summit and adjacent areas, including Cheonwang-bong, Inwang-bong, and Jiwang-bong, 2) Seoseok-dae (SS); 3) Ipseok-dae (IS); 4) Gwangseokdae (GS); 5) Sinseon-dae (SSD); and 6) Chotdae-bong, Buk-bong, and Heliport (Fig. 1 and Additional file 2: Figures S1 to S7). Because a large area of MMNG is covered by colonnade talus, the colonnades may have been more expansive than currently observed. Field campaigns also acquired morphological data and samples of the Mudeungsan Tuff for geochemical and chronological studies. 
The summit and adjacent regions (>1100 masl) of Mt. Mudeung, which consist of Cheonwang-bong (summit 1187 masl), Jiwang-bong, and Inwang-bong, are known for massive columnar joints of colonnades. The limited access resulting from the presence of an air force facility at the summit prevented a detailed evaluation. We obtained only limited information for the Jiwang-bong (Table 3 and Additional file 2: Figure S1a). We measured the face widths of the lower part of the columns using a tape measure because the face widths of the colonnades are fairly constant along the extents. Because most of the colonnades experienced substantial weathering and fracturing, we only measured intact columns of which the faces are relatively well preserved. We missed some face widths of the columns because the missed faces were inaccessible. We confirmed that the face widths of the colonnades are $\sim 1-3 \mathrm{~m}$, which implies that the diameters of the colonnades range from 2 to $3 \mathrm{~m}$. The Jigong talus on the southern slope of Mt. Mudeung (Additional file 2: Figure S1b) consists of colonnade debris from the summit and confirms that the colonnades at the summit experienced significant weathering and fracturing.

Columnar jointing of the Seoseok-dae (SS) colonnades is located approximately $800 \mathrm{~m}$ southwest of the summit of Mt. Mudeung. The exposed columnar joints range in elevation from 1050 to 1100 masl and extend approximately $30 \mathrm{~m}$ vertically and $150 \mathrm{~m}$ laterally (from north to south) (Fig. 1b and Additional file 2: Figure S2a, b). Horizontal cross sections of the colonnades show somewhat irregular pentagonal or hexagonal shapes, with the face widths varying from approximately 1.0 to $1.7 \mathrm{~m}$ (mean face width: $\sim 1.3 \mathrm{~m}$ ) (Table 3 ). Most column diameters exceed $2 \mathrm{~m}$ and persistent weathering has resulted in various vertical and horizontal fractures as secondary structures. Faces of colonnades usually lack distinct striae, except at the north end of the Seoseok-dae colonnades (Additional file 2: Figure S2c).

Columnar jointing of the Ipseok-dae (IS) colonnades (950 masl) are located $\sim 1 \mathrm{~km}$ southwest of the summit of Mt. Mudeung and $\sim 500 \mathrm{~m}$ away from the Seoseokdae colonnades (Fig. 1c and Additional file 2: Figure $\mathrm{S} 3 \mathrm{a})$. The face widths of the colonnades range from approximately 0.7 to $2.2 \mathrm{~m}$ (mean face width: $\sim 1.3 \mathrm{~m}$ ), and the column diameters are approximately 1.5 to $3 \mathrm{~m}$, similar to those of the Seoseok-dae colonnades (Table 3). Horizontal cross sections of the colonnades show that pentagonal or hexagonal shapes and secondary vertical and horizontal fractures are developed. Riedel shear-like joints are also observed in several columns, which implies that shear stress acted on the colonnades (Additional file 2: Figure S3b-d).

Columnar jointing of the Gwangseok-dae (GS) colonnades (850 masl) are 100 masl lower than the Ipseok- dae colonnades and approximately $\sim 950 \mathrm{~m}$ away to the southeast of the summit of Mt. Mudeung (Fig. 1a, d). The Buddhist temple Gyu-bong-am, stands on a plane seemingly formed by secondary horizontal fractures across the colonnades (Fig. 1d). These colonnades consist of pentagonal or hexagonal faces and have the largest face widths from 1.3 to $9 \mathrm{~m}$ (mean face width: $\sim 2.9 \mathrm{~m}$ ). The formation of foliation-like structure observed on the faces of the Gwangseok-dae colonnades resulted from the vertical compressive stress by the lithostatic pressure of hot ignimbrite accumulation. The hot clasts experienced flattening and stretching by welding compaction as a result (Additional file 2: Figure S4).

Columnar jointing of the Sinseon-dae (SSD) colonnades is found approximately $2.3 \mathrm{~km}$ away to the northeast of the summit of Mt. Mudeung (Additional file 2: Figure S5a) at approximately 750 masl, which is $100 \mathrm{~m}$ lower than the Gwangseok-dae colonnades. Well-developed pentagonal or hexagonal column faces are observed (Additional file 2: Figure $\mathrm{S} 3 \mathrm{~b}$ and $\mathrm{S} 5 \mathrm{~b}$ ). Face widths range from approximately 0.7 to $1.9 \mathrm{~m}$ (mean face width: $\sim 1.2 \mathrm{~m}$ ) (Table 3 ), which are slightly smaller than those of the Seoseok-dae and Ipseok-dae colonnades. Most colonnades have significant secondary fractures developed by weathering.

Several columnar joints of colonnades occur along the Baekma ridge extending from Jangbul-jae to Mt. Anyang. Several pentagonal or hexagonal faces in the Chotdae-bong colonnades are observed ( 800 masl) (Additional file 2: Figure S6). Due to safety issues, only a few columns were examined, but their sizes and the style of the columnar jointing are similar to those of the Ipseok-dae colonnades. Although columnar joints are observed in the colonnades distributed along the Baekma ridge, extensive talus exposed on the slope at the base of the ridge indicates that a much larger number of colonnades existed previously.

Other groups of columnar jointed colonnades occur in MMNG. Although many are obscured because of significant weathering and secondary jointing, several groups can be observed along the ridge from the ruins of the Donghwa-sa (Buddhist temple) to Jangbul-jae along the trail between the Ipseok/Gwangseok-dae colonnades and Buk-bong. Thus, there are vast extents of columnar joints of colonnades in MMNG (Additional file 2: Figure S7). Aerial photographs show numerous groups distributed across MMNG, which signal that Mt. Mudeung is a typical geologic feature associated with the 'Mountain of Columnar Joints'.

\section{Petrology, geochemistry, and zircon geochronology}

Some quartz-bearing Mudeungsan Tuff contains hyaline crystals. Tuff consisting of particles less than $2 \mathrm{~mm}$ is hyaline, and the remainder, which contains $>2 \mathrm{~mm}$ 
Table 3 Data of face widths

\begin{tabular}{|c|c|c|c|c|c|c|c|}
\hline Column number & Face 1 & Face 2 & Face 3 & Face 4 & Face 5 & Face 6 & Face 7 \\
\hline \multicolumn{8}{|c|}{ Jiwang-bong (unit: cm) } \\
\hline 1 & 210 & & & & & & \\
\hline 2 & 280 & 100 & 170 & & & & \\
\hline 3 & 170 & 120 & 90 & 310 & 200 & & \\
\hline 4 & 180 & 120 & 170 & & & & \\
\hline Mean face width & 177 & & & & & & \\
\hline \multicolumn{8}{|c|}{ Seoseok-dae (unit: cm) } \\
\hline 1 & 120 & 120 & 130 & 150 & 100 & & \\
\hline 2 & 160 & 110 & 170 & 130 & 110 & & \\
\hline 3 & 170 & 110 & 130 & & & & \\
\hline 4 & 120 & 100 & & & & & \\
\hline Mean face width & 129 & & & & & & \\
\hline \multicolumn{8}{|l|}{ Ipseok-dae (unit: cm) } \\
\hline 1 & 100 & 150 & 135 & 128 & & & \\
\hline 2 & 220 & & & 220 & & & \\
\hline 3 & 170 & & & 170 & & & \\
\hline 4 & 160 & 90 & & 125 & & & \\
\hline 5 & 150 & 90 & & 120 & & & \\
\hline 6 & 160 & 120 & & 140 & & & \\
\hline 7 & 116 & 165 & & 140 & & & \\
\hline 8 & 175 & & & 175 & & & \\
\hline 9 & 100 & 70 & 100 & 90 & & & \\
\hline 10 & 140 & 120 & 130 & 130 & & & \\
\hline 11 & 160 & 100 & 100 & 120 & & & \\
\hline 12 & 110 & & & 110 & & & \\
\hline 13 & 150 & 140 & & 145 & & & \\
\hline Mean face width & 134 & & & & & & \\
\hline \multicolumn{8}{|c|}{ Gwangseok-dae (unit: cm) } \\
\hline 1 & 180 & 180 & 350 & 360 & 400 & 280 & \\
\hline 2 & 230 & 160 & 300 & 280 & 210 & 210 & 290 \\
\hline 3 & 300 & 130 & 240 & 200 & & & \\
\hline 4 & 280 & 260 & 270 & 340 & & & \\
\hline 5 & 250 & 210 & 300 & 400 & 400 & 200 & \\
\hline 6 & 310 & 260 & 300 & & & & \\
\hline 7 & 910 & 135 & 310 & & & & \\
\hline 8 & 350 & 135 & 310 & 135 & & & \\
\hline 9 & 360 & 350 & 170 & 200 & 280 & 550 & \\
\hline Mean face width & 285 & & & & & & \\
\hline \multicolumn{8}{|l|}{ Sinseon-dae (unit: cm) } \\
\hline 1 & 125 & 90 & 100 & 90 & 90 & & 99 \\
\hline 2 & 110 & 100 & 140 & 135 & 90 & & 115 \\
\hline 3 & 100 & 80 & 70 & 110 & 115 & 90 & 95 \\
\hline 4 & 140 & 250 & 90 & 70 & 90 & 70 & 118 \\
\hline
\end{tabular}


Table 3 Data of face widths (Continued)

\begin{tabular}{lllllll}
\hline 5 & 120 & 190 & 115 & 160 & 140 & 145 \\
6 & 110 & 140 & 130 & 170 & 137.5 \\
7 & 170 & 130 & 150 & 150 & 150 \\
Mean face width & 121 & & & & \\
\hline
\end{tabular}

particles, includes crystals that were deposited at the same time as volcanic activities and bed lithic rock fragments (Fig. 3a). Under a microscope, shards are elongated as lenticular shapes (fiammes) and exhibit a eutaxitic fabric and extreme welding. Few cuspate shard shapes remain, and the ends of the rock fragments are round and smooth. The crystalline tuffs in the matrix are partly devitrified and are wrapped around crystals. Elongated vesicles in these crystals are commonly, but not consistently, parallel to the foliation (Fig. 3a, b). In addition, welded structures are observed at the hyaline base, which suggests that the Mudeungsan Tuff is partially welded. According to conventional studies of the formation process of welded tuff, a certain tuff floor was re-welded by the remaining heat in the tuff layers after the emplacement of the tuff (Park et al., 2005). This is plausible in that the thickness of the whole-rock body of the quartz-bearing andesitic tuff found in Mt. Mudeung and that its adjacent regions are approximately $600 \mathrm{~m}$ (Fig. 4). This also indicates that the emplacement of the tuff occurred on relatively planar ground, resulting in thick tuff emplacement, which is supported by a zonal structure with clear crystal boundaries. Microscopic observations show regular boundaries of the twinning plane in the Mudeungsan Tuff (Fig. 3c, d).

The Mudeungsan Tuff includes crystals of plagioclase, alkali feldspar, quartz, biotite, and clinopyroxene. Lithic fragments include volcanic and country rocks (Fig. 3c, d). Plagioclase grains are panidiomorphic or subhedral; their contact points can alternate, showing repeated twin crystals (double crystal) or zonal structures. Weak sericite alteration, caused by weathering, is also observed in some plagioclase phenocrysts. The substrate in which plagioclase is observed was welded and some plagioclase phenocrysts, along with the welded structures, underwent devitrification.

Sericitization is observed in some crystals resulting from increased potassium (K) content, but only moderate alteration (e.g., albitization) is observed. This might have resulted from acidic igneous activity related to the origin of the andesite during the Cretaceous. Oxide variations are correlated with the amounts of silica $\left(\mathrm{SiO}_{2}\right)$ and have inverse proportions of $\mathrm{MgO}$ and $\mathrm{CaO}$ to $\mathrm{SiO}_{2}$. $\mathrm{K}_{2} \mathrm{O}$ is correlated to $\mathrm{SiO}_{2}$, and $\mathrm{P}_{2} \mathrm{O}_{5}$ showed little change. Increasing proportions of oxides relative to silica are similar to the general geochemical occurrence of the Cretaceous volcanic rocks in Korea, and the Mudeungsan
Tuff are also generated from calc-alkaline magma in the volcanic arc environment (Fig. 5).

The primitive mantle-normalized pattern shows that the elements of $\mathrm{Cs}, \mathrm{Rb}, \mathrm{Ba}, \mathrm{La}$, and Ce were enriched, whereas those of $\mathrm{Nb}, \mathrm{Sr}$, and $\mathrm{Zr}$ were depleted. High values of $K$ and $R b$, with a low $K / R b$ ratio (10.3-25.4) were observed (Fig. 6a). Large-ion lithophile elements (LILE) such as $\mathrm{K}$ and $\mathrm{Rb}$ are generally enriched in the volcanic rocks of arc volcanoes compared with those of mid-ocean ridges (Table 2). However, high-fieldstrength elements (HFSE) such as $\mathrm{Zr}$ and $\mathrm{Nb}$ are depleted in volcanic rocks of arc volcanoes compared with those of mid-ocean ridges. The $\mathrm{Ba} / \mathrm{La}$ ratio of the tuff ranges from 19.5 to 25.8 , which corresponds to the range $(\mathrm{Ba} / \mathrm{La}=8.0-13.5)$ of arc volcanoes (Gill, 1981). The $\mathrm{Zr} / \mathrm{Nb}$ ratios of the tuff range from 2.3 to $\sim 38$, which generally corresponds to the $\mathrm{Zr} / \mathrm{Nb}$ ratio $(10 \sim 20)$ of island and continental arcs (Gill, 1981). Therefore, the Mudeungsan Tuff is similar to continental arc rocks with high $\mathrm{Sr}$ (334-502). It also contains low HFSE (Cr, Nb, and $\mathrm{Zr}$ ) and lacks compatible elements such as $\mathrm{Co}$ and Sc, which have higher alkali concentrations than light rare-earth elements (LREE). Patterns of the rare-earth element distributions do not show clear fractionation between LREE and HREE (LREE/HREE = 16.2-19.4). The Mudeungsan Tuff also retains slight Eu anomalies. Minor negative Eu anomalies typically corresponded to the calc-alkali volcanic zone of the continental crust of the Pacific Rim (Fig. 6b).

High $T h / U$ values $(>1)$ of all zircons suggest that they originated from igneous activity (Hoskin and Black, 2000). Representative ages of zircons from the upper Ipseok-dae, lower Seoseok-dae, Gwangseok-dae, and Chotdae-bong colonnades are $84.73 \pm 0.81,85.82 \pm 0.84$, $85.41 \pm 0.58$, and $87.72 \pm 0.59 \mathrm{Ma}$, respectively (Fig. 7). Except for those of the Chotdae-bong colonnades, the ages of all of the colonnades fall within the margin of error. The slightly older ages of the Chotdae-bong colonnades indicate that they were formed by an earlier tuff emplacement in the late Coniacian, and that the Ipseokdae and Seoseok-dae colonnades were subsequently emplaced in the early Campanian (see Additional file 1; Table S1 for the SHRIMP U-Pb zircon results).

\section{Scaling analysis and numerical modeling}

The welded tuff in MMNG is not geochemically distinguishable. In addition, the absolute ages of welded tuff 

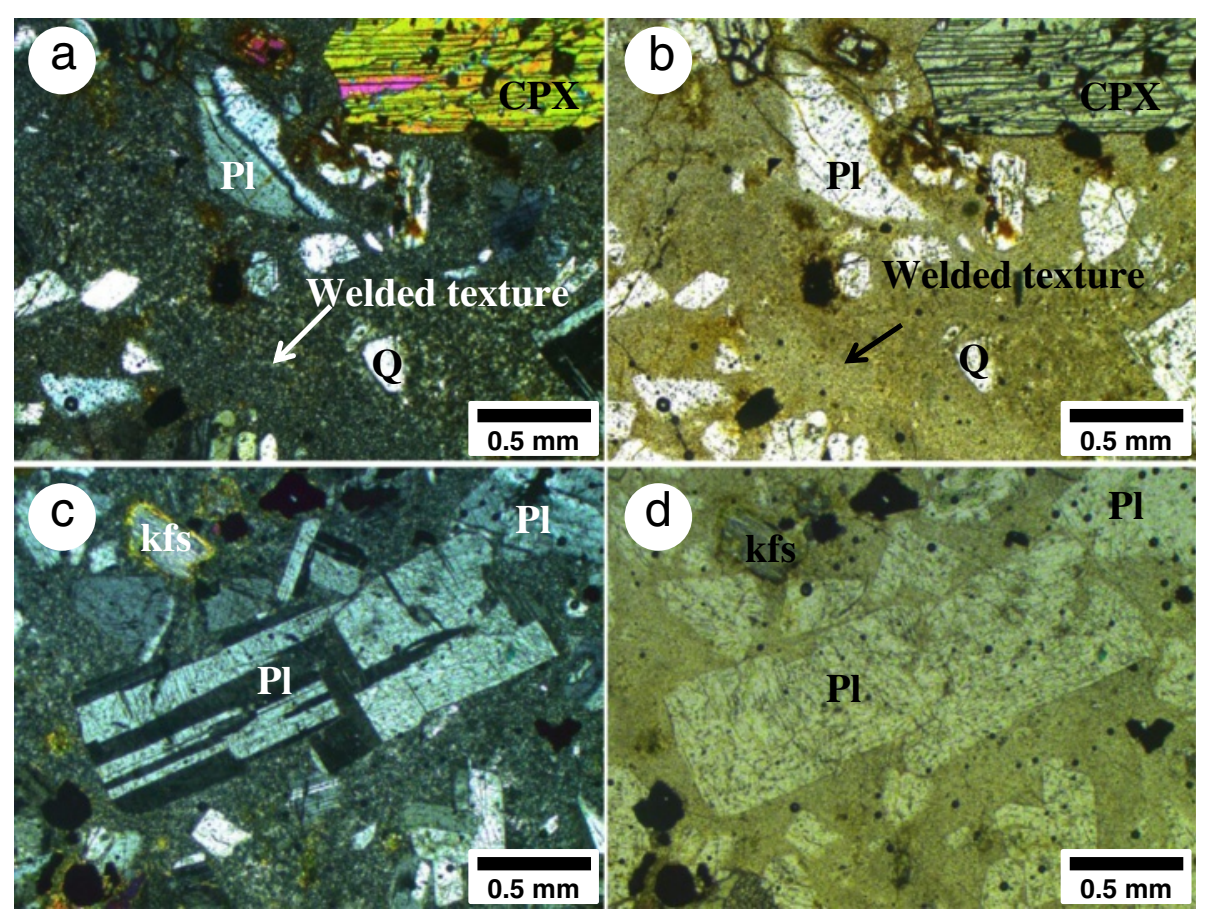

Fig. 3 Petrographic images of the Cretaceous Mudeungsan Tuff (quartz-bearing andesitic-dacitic tuff) of Mt. Mudeung. a-b Thin section of slightly welded textures of the Mudeungsan Tuff with quartz and plagioclase phenocrysts in a matrix of welded glass shards in plain and cross-polar light, respectively. c-d Zoned plagioclase phenocrysts have albite twins and quartz is fine-grained and found in the groundmass. PI plagioclase, Q quartz, kfs K-feldspar (sanidine), and CPX clinopyroxene

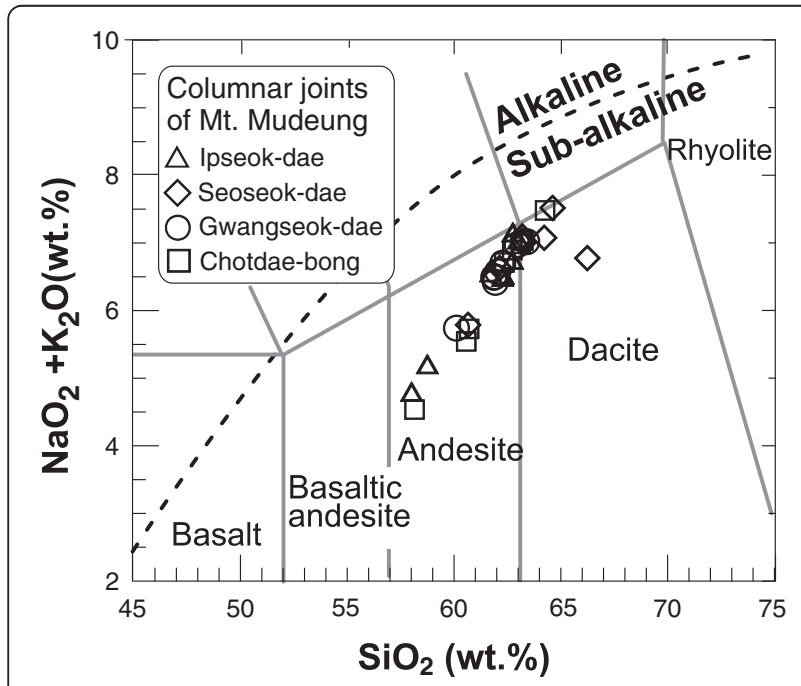

Fig. 4 Mt. Mudeung andesite or dacite plotted on the total alkali-silica igneous rock classification diagram. Each symbol represents an average colonnade composition ( $n=15-26$; see Table 1) from Mt. Mudeung. Rock samples were collected at the Ipseok-dae (unfilled triangles), Seoseok-dae (unfilled diamonds), Gwangseok-dae (unfilled circles), and Chotdae-bong (unfilled rectangles) colonnades. Dotted line indicates the boundary between alkaline and sub-alkaline magmas (Le Bas et al., 1986), and all samples from Mt. Mudeung are plotted within the sub-alkaline field fall within a margin of error, except for the Chotdaebong colonnades which are $\sim 2$ Ma older than the others. Therefore, all of the colonnades of the welded tuff, except for the Chotdae-bong colonnades, seem likely to have been established by one massive emplacement of the andesitic-dacitic tuff. However, because the face widths of colonnades are inversely proportional to the growth rate of columnar joints from the cold margin (Goehring et al., 2009; Grossenbacher and McDuffie, 1995), variation in the face widths of the colonnades with elevation implies several discontinuous episodes of tuff emplacement, cooling, and compaction in MMNG, rather than a single event occurring after the earlier tuff emplacement resulting in the Chotdae-bong colonnades. Because striae are observed only at the north end of the Seoseok-dae colonnades, the growth rate of the columnar joints cannot be determined using striae spacing.

Although the quantity of the field data is limited, the face widths of the welded tuff vary with elevation. In addition, Park et al. (2005) showed that the tuff emplacements that generated the Mt. Mudeung colonnades experienced little flow, which implied that the lava was emplaced on a nearplanar surface. Thus, we can hypothesize that the formation of the columnar joints of the welded tuff occurred in the emplaced tuffs without lateral deformation. If the tuff was emplaced separately, within a time span shorter than the 


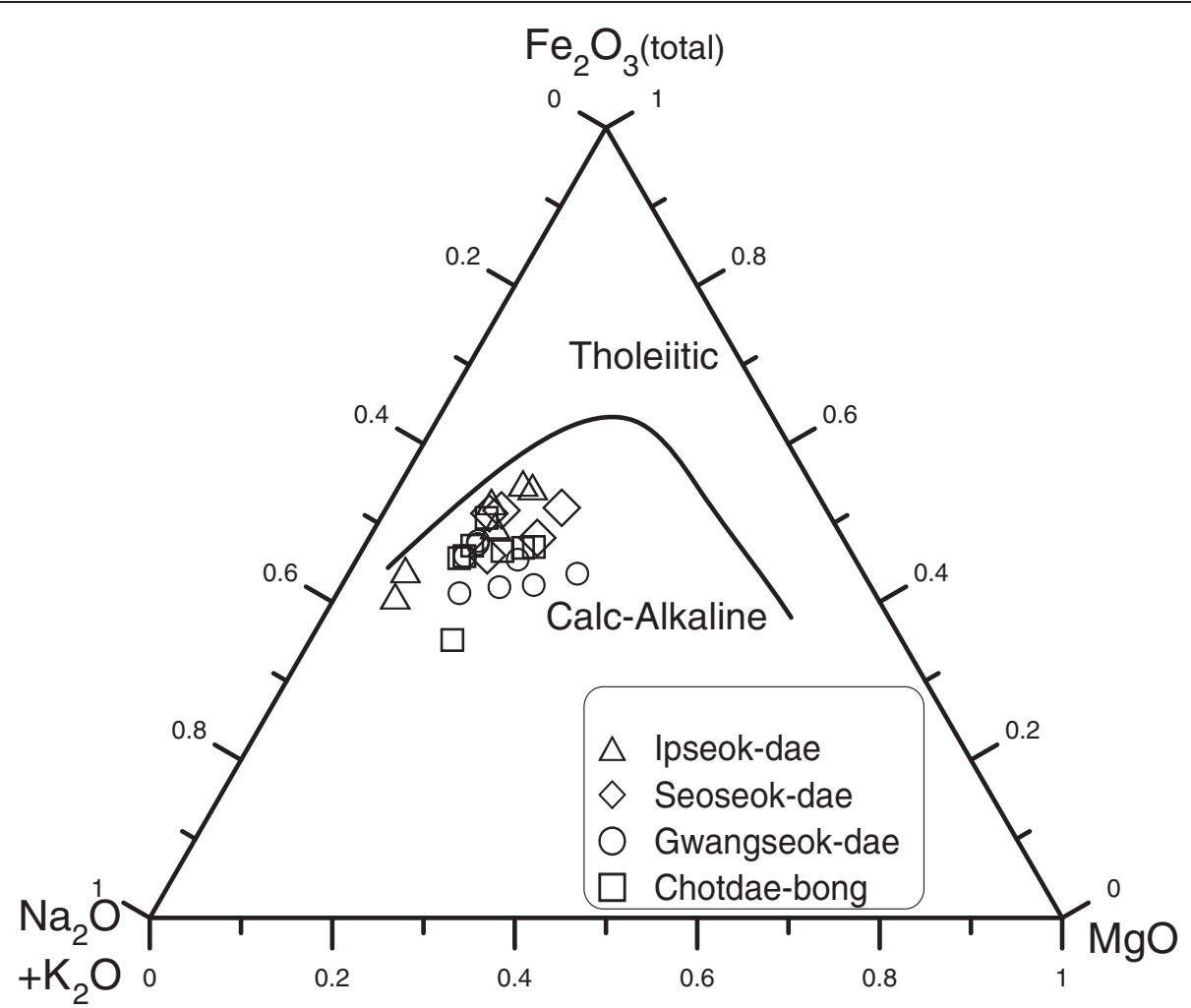

Fig. 5 AFM diagram showing whole-rock composition in terms of $\mathrm{Na}_{2} \mathrm{O}+\mathrm{K}_{2} \mathrm{O}$, total iron as $\mathrm{FeO}$ and $\mathrm{MgO}$. Rock samples were collected at the Ipseok-dae (unfilled triangles), Seoseok-dae (unfilled diamonds), Gwangseok-dae (unfilled circles), and Chotdae-bong (unfilled rectangles) colonnades. The dotted line indicates the boundary between calc-alkaline and tholeiitic series derived by Irvine and Baragar (1971). The trend of analyses of samples from Mt. Mudeung is a representative of calc-alkaline arc volcanos

standard deviation of the age dating, welded tuff at the summit area of Mt. Mudeung (> 1100 masl) could have been generated by tuff emplacement onto previously existing tuff emplacement $(<\sim 1100$ masl $)$ because the face widths of these colonnades are larger than those of the underlying colonnades. These underlying colonnades can be divided into upper and lower colonnades because the mean face width $(\sim 1.3 \mathrm{~m})$ of the upper colonnades (Seoseok-dae and Ipseok-dae colonnades are found from $\sim 950$ to $\sim 1100$ masl) is much smaller than that $(\sim 2.9 \mathrm{~m})$ of the lower colonnades (Gwangseok-dae colonnades are found above $\sim 850$ masl and assumed to be extended to $~ 950$ masl, which is at the bottom of the Ipseok-dae colonnades). The ratio of the vertical extent of the upper colonnades to that of the lower colonnades (6:4) is consistent with their differences in extent $(150$ to $100 \mathrm{~m})$, which indicates that the two colonnades resulted from a single thick tuff emplacement (thickness: $\sim 250 \mathrm{~m}$ ). The colonnades at the lowest elevation ( 700 to 850 masl) had a much smaller mean face width $(1.2 \mathrm{~m})$ than did the overlying lower colonnades $(2.9 \mathrm{~m})$, so the lower colonnades must have been formed from an earlier tuff emplacement. This scaling analysis suggests that three separate tuff emplacements generated the welded tuff found in Mt. Mudeung from $\sim 700$ to 1187 masl (summit), excluding the Chotdaebong colonnades.

However, it is not clear whether the extents and face widths of colonnades are reasonably correlated, especially whether the face widths of the upper and lower colonnades from 850 to 1100 masl are consistent with the extent of the observed colonnades. If face widths and growth rates are correlated, the growth rate of the columnar joints of the colonnades should be consistent with the larger face widths. Therefore, we conducted a scaling analysis and ran simple numerical models that evaluated the relationship between the thicknesses of the tuff and the face width (or growth rate) of the columnar joints of the colonnades.

Goehring et al. (2009) suggested a scaling equation that relates joint spacing to the growth rate of columnar joints after evaluating the columnar joint-like fractures that develop in drying slurries of corn starch. Although the equation is based on a series of desiccation experiments, the analogy between water evaporation and thermal diffusion indicates that the scaling equation is 

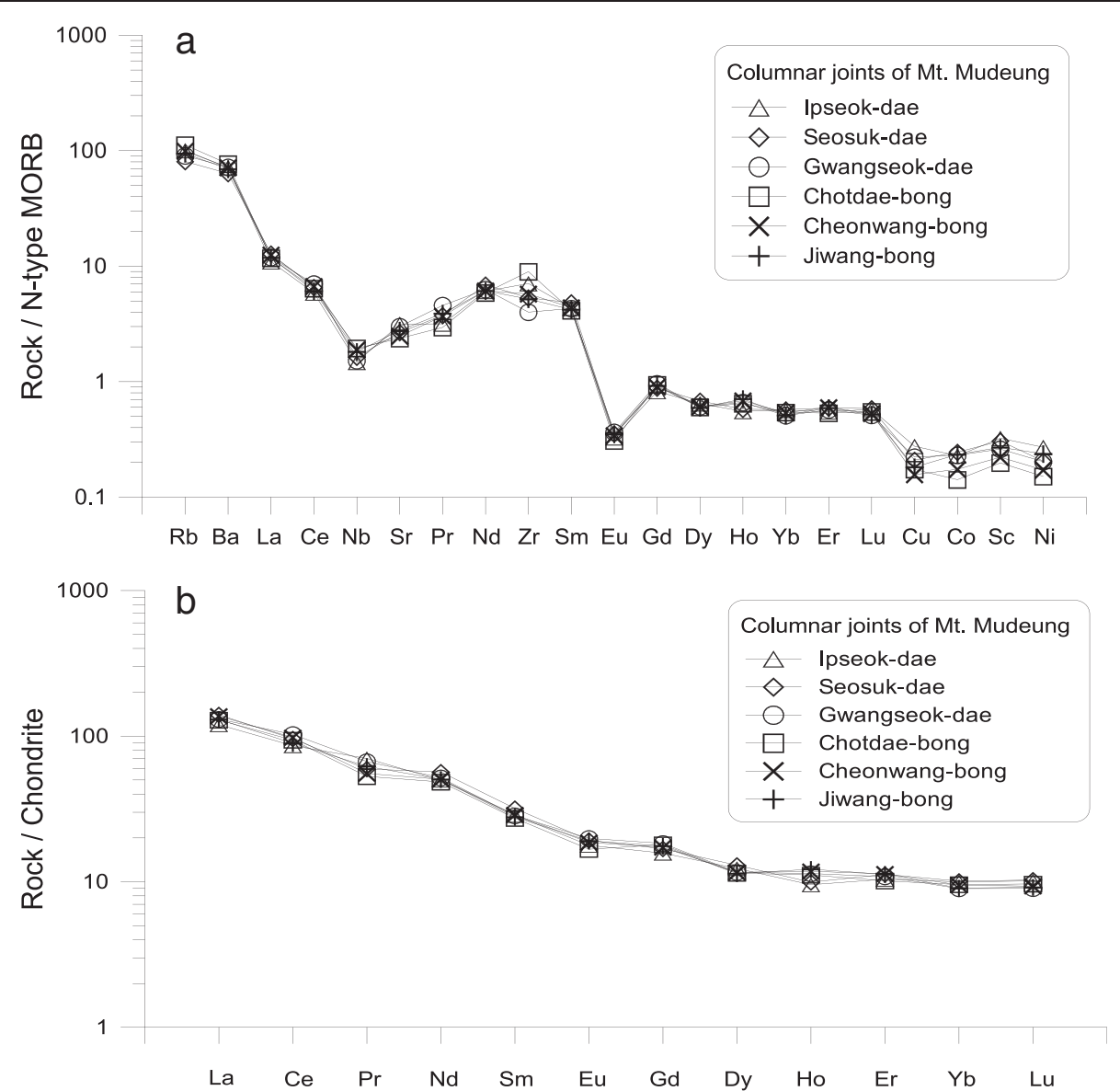

Fig. 6 Trace element variation diagrams of welded tuff in Mt. Mudeung. a N-type MORB-normalized trace element variation diagram and b chondrite-normalized trace element variation diagram. Neither diagrams show distinct genetic differences among the Mudeungsan Tuff. Samples are grouped according to the clusters in Fig. 5. Normalizing values are from McDonough and Sun (1995)

applicable to the growing columnar joints in cooling tuff emplacements. The scaling equation can be expressed as:

$$
P e=\frac{v L_{c}}{D_{p}} \sim \frac{v \sqrt{\pi r^{2}}}{\frac{k}{\rho c_{p}}} \text { (Goehring et al. 2009). }
$$

where $P e$ is the Peclet number, $v$ is the growth rate of the columnar joint, $L_{c}$ is the joint spacing, $D_{p}$ is the thermal diffusivity, $k$ is the heat conductivity, $\rho$ is the rock density, and $c_{p}$ is the heat capacity. The joint spacing corresponding to the area of a cross section of a column is difficult to estimate because such cross sections are often irregular. Therefore, a simple approximation of the area of the cross section was used by assuming that the cross section of the columnar joints can be expressed as the area of a circle $\left(\pi r^{2}\right)$ enclosing the cross section of the column (Fig. 8b). This approximation is useful if the column consists of five or six faces because the face width can be used for the radius of the circle $(r)$.

The scaling equation indicates that if the Peclet number and thermal diffusivity of the cooling column are constants, the growth rate of the columnar joint is inversely proportional to the face width of the column:

$$
v_{\text {columnar joint }} \propto \frac{1}{d_{\text {face width }}}
$$

where $d$ is the face width of the column. This is consistent with studies suggesting an inverse relation between the cooling rate and face width of the columns (Goehring et al., 2009; Grossenbacher and McDuffie, 1995). For example, if the ratio of the face widths of the upper to lower colonnades is $4: 6$, the ratio of the extents of the upper to lower colonnades becomes 6:4. The ratio of the mean face widths of the upper $(1.3 \mathrm{~m})$ and lower $(2.9 \mathrm{~m})$ colonnades is approximately $3: 7$, which is comparable to the ratio (6:4) of the extents of the upper and lower colonnades (i.e., $150 \mathrm{~m}$ from $\sim 950$ to $\sim 1100$ masl; $100 \mathrm{~m}$ from $\sim 850$ to $\sim 950$ masl). The extents of the upper and lower colonnades are also consistent with the ratio (6:4) of the upper to lower colonnades from the numerical modeling. This finding indicates that the group of columnar joints of colonnades from 850 


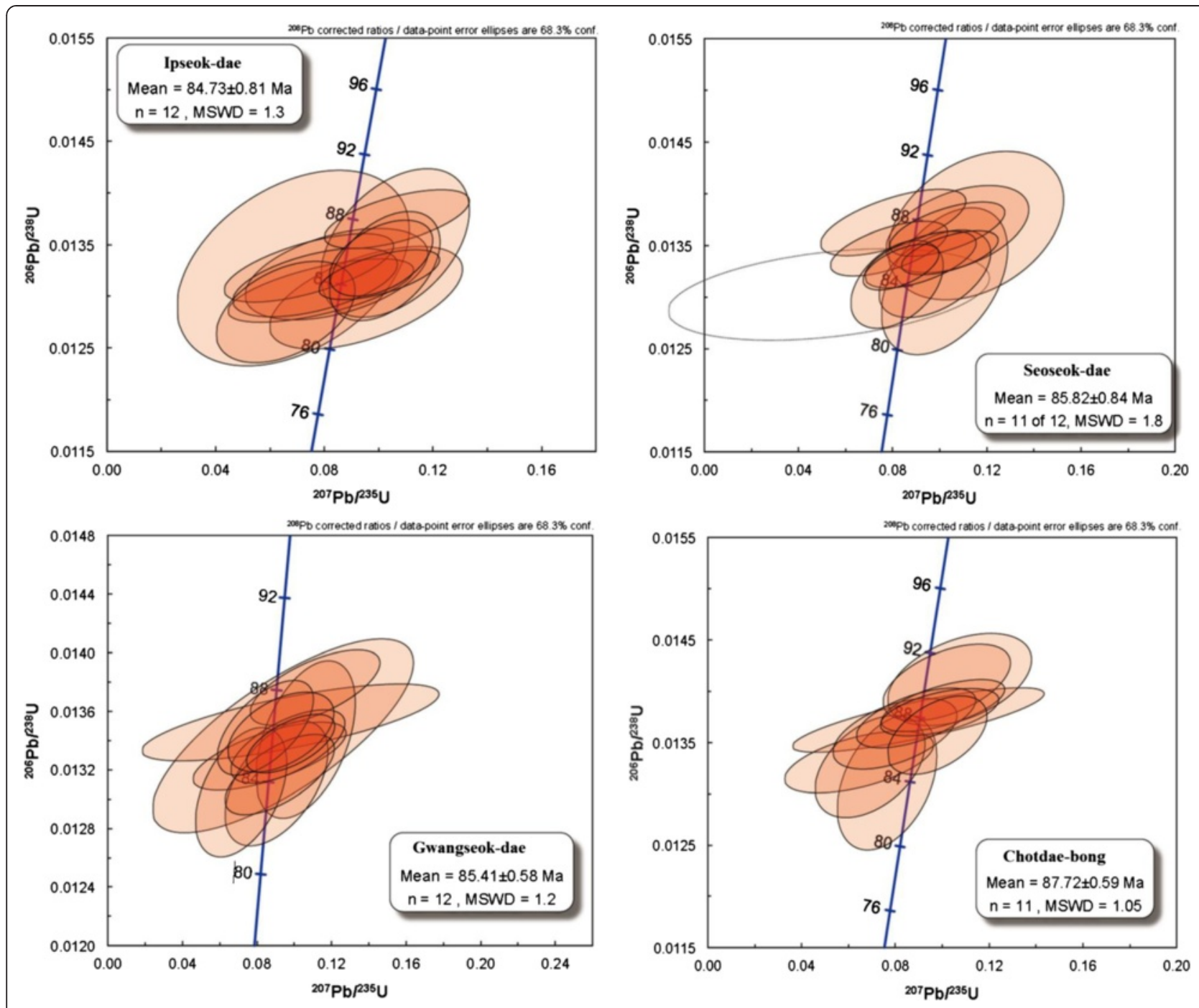

Fig. 7 Concordia diagrams showing calculated U-Pb ages from concordant zircon for Mt. Mudeung (lpseok-dae: $84.73 \pm 0.81$ Ma; Seoseok-dae: $85.82 \pm 0.84 \mathrm{Ma}$; Gwangseok-dae: $85.41 \pm 0.58 \mathrm{Ma}$; and Chotdae-bong: $87.72 \pm 0.59 \mathrm{Ma}$ ). The analysis error ellipses are $1 \sigma$

to 1100 masl in Mt. Mudeung may result from cooling of a single tuff emplacement, divided into upper and lower colonnades corresponding to the Seoseok-dae/Ipseok-dae and Gwangseok-dae colonnades, respectively. It also indicates that water infiltration along the columnar joints accelerated the propagation rate of the columnar jointing, resulting in the larger extent of the upper colonnade compared with the lower colonnade, as evidenced by the relatively constant face widths of the upper (Seoseok-dae and Ipseok-dae) and lower (Gwangseok-dae) colonnades.

Although the scaling analysis described above implies that welded tuff in the intermediate region of $\mathrm{Mt}$. Mudeung were formed during a single tuff emplacement, it does not answer whether the growth rate of the columnar joints and the face width satisfy reasonable Peclet numbers ranging from 0.1 to 0.5 (Goehring et al., 2009).
Previous studies have shown that columnar joints are generated when the thermal stress caused by contraction exceeds the yield strength of the solidified rock (Spry, 1962). Although the yield strength of the rock depends on temperature, composition, and grain size, it is generally accepted that columnar joints form when the propagating temperature field reaches the glass transition temperature of the rock. Therefore, the growth rate of the columnar joints can be estimated by evaluating the temperature field. Because the cooling of the tuff is governed by conduction and water infiltration along columnar joints, which keeps the growth rate of the columnar joints constant (Goehring et al., 2009; Grossenbacher and McDuffie, 1995), it is essential to evaluate the cooling history of the tuff. As a result, we formulated a one-dimensional numerical model with several assumptions, as described below. 
a Upper and Lower Colonnades

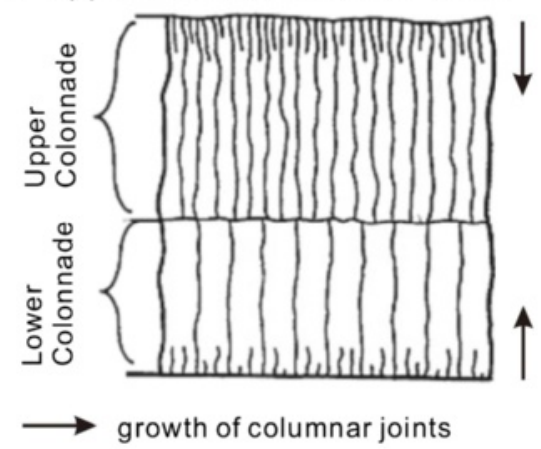

b Column Parameters

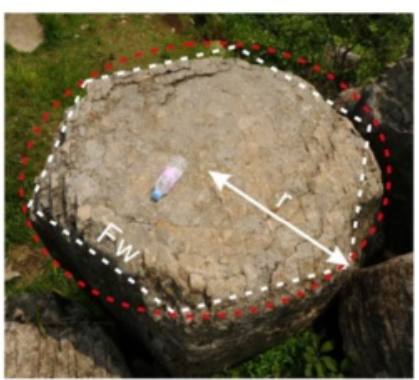

Fw: face width

r: radius of enclosing circle

Fig. 8 Schematic diagram of the upper and lower colonnades showing columnar joints and column parameters. a Columnar joints growing from the top and bottom of the tuff emplacement result in the upper and lower colonnades with smaller and larger face widths, respectively. The figure is modified from Grossenbacher and McDuffie (1995). b The column parameters used in this study. Fw and $r$ are the face width and radius of the circle enclosing a column cross section, respectively. The pentagon and circle reflect a perspective effect. The column was in the Sinseon-dae colonnade, and the water bottle is approximately $20 \mathrm{~cm}$ in height

First, we assumed that heat transfer in the cooling tuff is governed only by conduction. However, because water infiltration along columnar joints effectively transfers heats from the deeper column to the margin, the growth rate of the columnar joints might be almost constant regardless of depth; therefore, the face width is also kept constant. Field observations show that the joint spacing (face width) of the columnar joints of colonnades in Mt. Mudeung is fairly constant along the extents; therefore, water infiltration effectively transfers the internal heat of the colonnades along columnar joints. To consider the effect of water infiltration, we assumed that the propagation rate of the temperature field in the early cooling stage represents the effective cooling rate maintained throughout the colonnades. Second, we neglected the discontinuous growth of columnar joints, which are expressed as straie, by assuming that the joint spacing grows constantly. Third, we assumed that deformation was occurring because the emplacement of the tuff was negligible, as evidenced by the minimal internal flow structure, high viscosity of the dacitic tuff, and a paucity of linear fractures caused by tuff flow that was demonstrated by field works (Lodge and Lescinsky, 2009a, b; Park et al., 2005). Fourth, we assumed that thermodynamic parameters such as thermal conductivity and heat capacity do not depend on temperature and pressure. Finally, we assumed that heat transfers only vertically along the welded tuff and that no lateral heat transfer occurs; one-dimensional heat conduction along the welded tuff was used to evaluate the Peclet numbers of the welded tuff.

Given these assumptions, we set the thickness of the tuff at $250 \mathrm{~m}$ (domain 1), with an underlying 700-mthick rock layer (domain 2; Fig. 9a). Tuff thickness represents the entire thickness of the upper and lower colonnades between 850 and 1100 masl. For reasonable thermodynamic parameters (Turcotte and Schubert, 2002), we used $1000 \mathrm{~J} / \mathrm{kg} \cdot \mathrm{K}$ for the heat capacity, $2700 \mathrm{~kg} / \mathrm{m}^{3}$ for the density, and $2.7 \mathrm{~W} / \mathrm{m}$ for the thermal conductivity (thermal diffusivity: $10^{-6} \mathrm{~m}^{2} / \mathrm{s}$ ) throughout both domains. Columnar jointing occurs when the thermal stress exceeds the yield strength of the rock; thus, we simply assumed that joints occur instantaneously when the temperature falls below the glass transition temperature, which is assumed here to be $900{ }^{\circ} \mathrm{C}$ (Peck and Minakami, 1968). For boundary conditions, we assume that both the top (air) and bottom (underlying rock) temperatures of the domains were $0{ }^{\circ} \mathrm{C}$. For the initial conditions, we assumed $1000{ }^{\circ} \mathrm{C}$ for the tuff (domain 1) and $0{ }^{\circ} \mathrm{C}$ for the underlying rock layer (domain 2). The tuff loses heat through the air (top boundary) and the underlying ground by conduction. The finite element code, COMSOL Multiphysics ${ }^{\circ}$ (www.comsol.com) was used to conduct the numerical calculations. Domains were decomposed into 950 equidistant elements $(1 \mathrm{~m}$ per element). To calculate the temperature field, model runs for 100 years were made by saving the $900{ }^{\circ} \mathrm{C}$ temperature contour every 5 years.

Figure $9 \mathrm{~b}$ shows growth rates of the columnar joints corresponding to the upper and lower colonnades estimated using the $900{ }^{\circ} \mathrm{C}$ isothermal contour. Because the heat flux via conduction is large at the upper margin of the welded tuff, the columnar joints grow faster near the margin. Furthermore, because the temperature gradient decreases with time, the growth rate of the columnar joints also decreases (from 0.1839 to $0.0317 \mu \mathrm{m} / \mathrm{s}$ ). The decreasing growth rate of the columnar joints increased at an intermediate depth of the tuff (e.g., $0.0317 \mu \mathrm{m} / \mathrm{s}$ at a depth of $87.5 \mathrm{~m}$ to $0.0666 \mu \mathrm{m} / \mathrm{s}$ at a depth of $116.6 \mathrm{~m}$ in the upper colonnade). The style of the growth rate is similar to the style of the cooling rate because the 


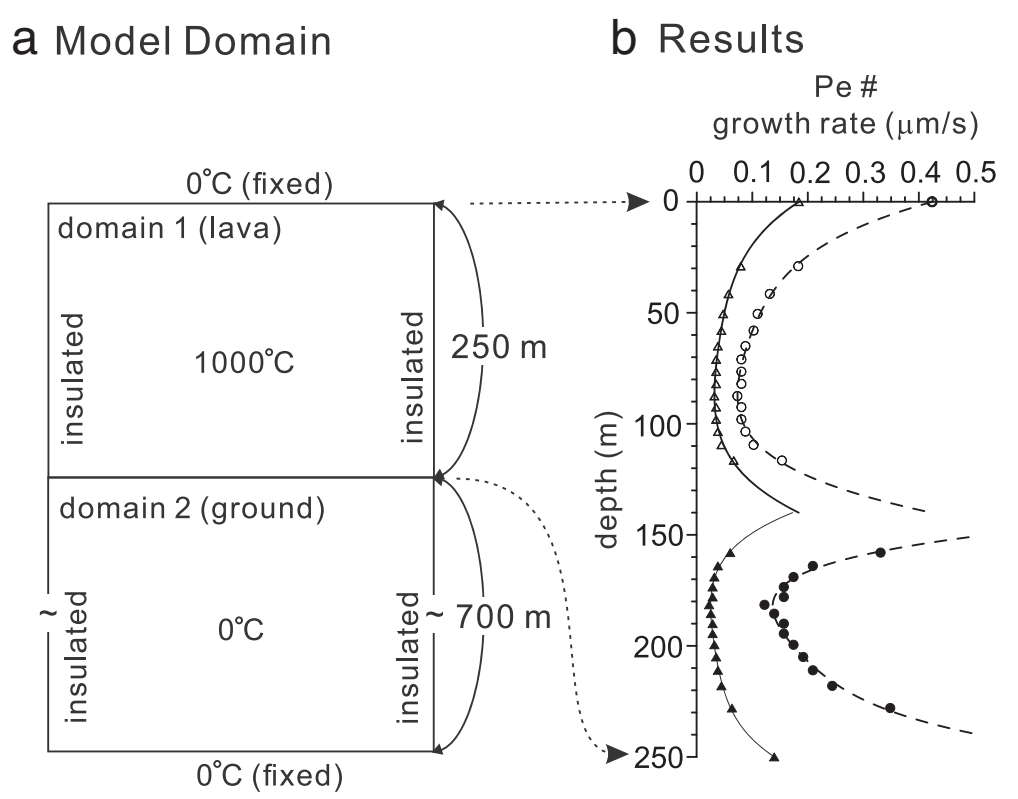

Fig. 9 a Schematic diagram of the model domain simulating the cooling of a tuff emplacement on the ground. Thicknesses of the tuffs (domain 1) and ground (domain 2) are assumed to be 250 and $700 \mathrm{~m}$, respectively. Lateral walls of domains 1 and 2 are insulated, reflecting the fact that the horizontal length of the model domain is much longer than the vertical length of the domain. $\mathbf{b}$ Locations of the $900{ }^{\circ} \mathrm{C}$ isotherm (line) and corresponding Peclet numbers (dashed line) every 5 years. The triangle and circle represent the growth rate of the columnar joints and the corresponding Peclet number, respectively. The unfilled and filled symbols represent the upper and lower colonnades, respectively. The growth rate $(\mathrm{mm})$ of columnar joints and the Peclet number were evaluated using the depth of the isotherm. Isotherms from the upper and lower colonnades meet at a depth of approximately $140 \mathrm{~m}$, which is consistent with Grossenbacher and McDuffie (1995)

growth rate of the columnar joints is proportional to the cooling rate. The corresponding Peclet numbers for the upper and lower colonnades vary with the growth rate (e.g., $0.424,0.073$, and 0.153 at the margin $(0 \mathrm{~m}$ depth), $87.5 \mathrm{~m}$ depth, and $116 \mathrm{~m}$ depth, respectively). Our numerical experiment confirmed that the ratio of the upper to lower colonnades was $\sim 6: 4$, which is consistent with a previous study (Grossenbacher and McDuffie, 1995).

As discussed above, water infiltration along columnar joints could keep the growth rate of the columnar joints relatively constant with depth. Therefore, it might be plausible for the growth rate of the columnar joints at the upper margin to be maintained throughout the tuff. If we assume that the median Peclet number of 0.3 was kept during the entire cooling, we can assume that a growth rate of $0.1302 \mu \mathrm{m} / \mathrm{s}$, corresponding to the growth rate of the columnar joint in the upper colonnades at $\sim 11 \mathrm{~m}$ depth, was kept constant throughout the upper colonnades. Then, if we also assumed that a Peclet number of 0.3 for the lower colonnades, the modified growth rate of the columnar joints that formed in the lower colonnade is taken as $0.0584 \mu \mathrm{m} / \mathrm{s}$, which is comparable to the growth rate of the columnar joints of the lower colonnade as constrained by our numerical calculations (Fig. 9).

Although our numerical model does not consider the effect of water infiltration, which keeps the growth rate of columnar joints constant, the estimated growth rates of the columnar joints in the 250-m-thick tuff emplacement using a Peclet number of 0.3 are plausible in light of the numerical calculations. The scaling analysis and numerical calculations indicates that welded tuff at elevations of $850 \sim 1100 \mathrm{~m}$ can be generated by a single tuff emplacement that decomposed into the upper and lower colonnades. This finding also implies that Mt. Mudeung resulted from at least three discontinuous tuff emplacements: the third (>1100 masl), second (850-1100 masl), and first $(<850$ masl) tuff emplacements.

\section{Genesis of columnar joints of colonnades at Mt. Mudeung} This study indicates that columnar joints of the colonnades in MMNG resulted from cooling of tuff and that the foliation-like structures are consequences of the welding of the tuff. Here, we suggest that the genesis of the columnar joints of the colonnades in Mt. Mudeung resulted from the collapse of the emptied magma chamber and subsequent tuff depositions on the collapsed caldera. Before a large amount of magma erupted in MMNG, the underlying magma chamber was inflated by the injection of magma. After a large amount of magma in MMNG was erupted, the emptied chamber was unable to support the weight of the volcanic edifice above it, and it collapsed. The resulting tuff experienced cooling, compaction, and welding. With further cooling, the welded tuff developed columnar joints from the surface 


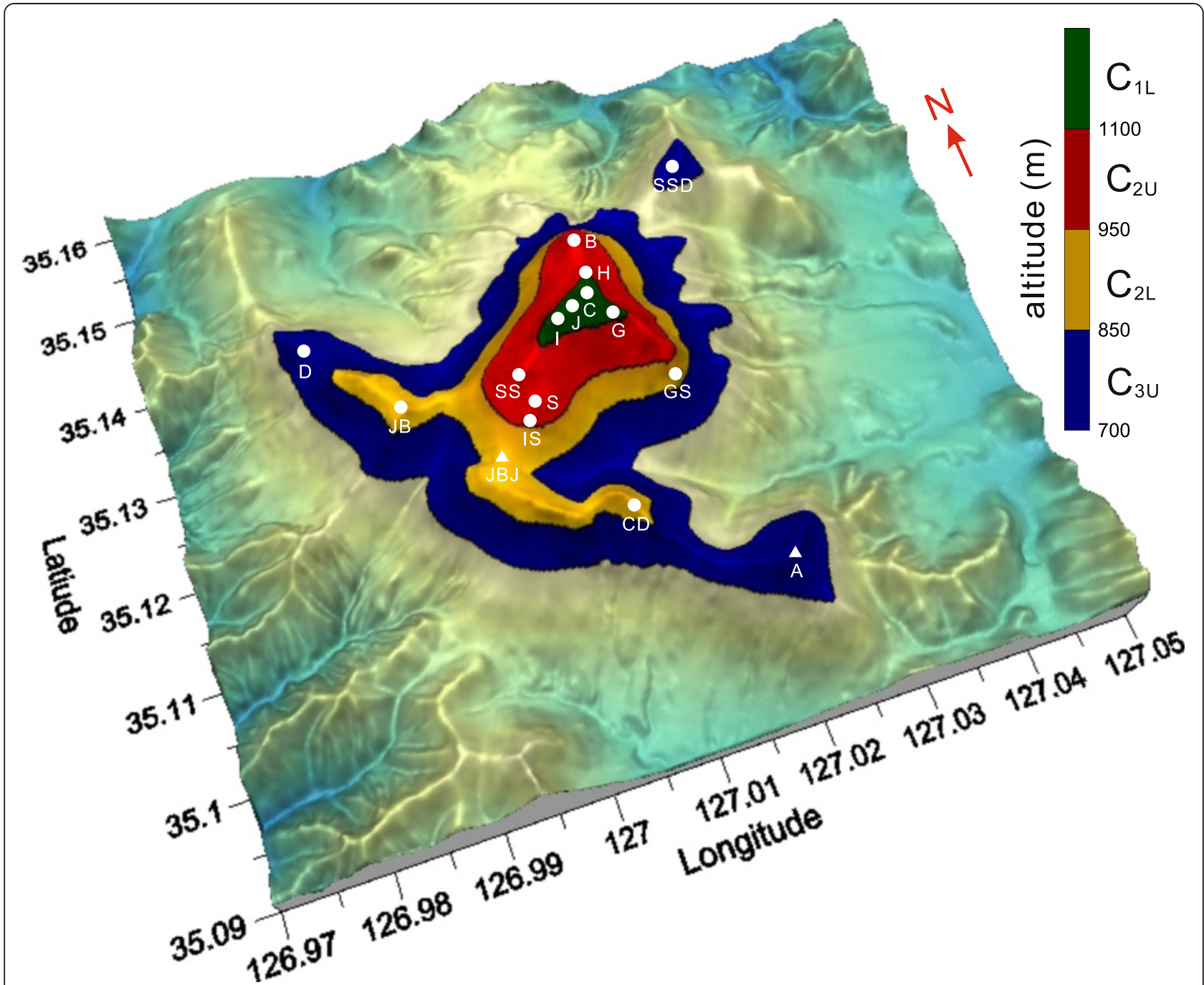

Fig. 10 Elevation-dependent distribution of colonnades using a scaling analysis and numerical model calculations with the same naming convention used in Fig. 2. Major colonnades are described as D (Donghwa-sa), JB (Jung-bong), JBJ (Jangbul-jae), CD (Chotdae-bong), A (Mt. Anyang), IS (Ipseokdae), S (small-scale colonnades), SS (Seoseok-dae), I (Inwang-bong), J (Jiwang-bong), C (Cheonwang-bong), G (Gyu-bong), H (Gate of the Air force facility), B (Buk-bong) and SSD (Sinseon-dae). $C_{1 L}$ (green) represents the lower colonnades at the summit area of Mt. Mudeung. $C_{2 U}$ (red) and $C_{2 L}$ (yellow) represent the upper and lower colonnades exposed at intermediate elevations on Mt. Mudeung. $C_{3 \cup}$ (blue) represents the upper colonnades occupying the lowest regions of Mt. Mudeung. Because the Chotdae-bong colonnades are 2 million years older than the other colonnades, welded tuff along the ridge between Jangbul-jae (JBJ) and Mt. Anyang (A) may have been separately formed

and bottom of each tuff corresponding to the upper and lower colonnades. There were at least three tuffs depositions, and they developed elevation-dependent colonnades in Mt. Mudeung. The ring-shaped Gwangju porphyritic granite was intruded as a ring dyke in the tuff, as shown in the western area of Mt. Mudeung. This is considered to be the solidified ring dyke formed after the pyroclastic material was charged after the vent of the volcano was formed. Major collapse may follow as a consequence of the eruptive removal of magma due to the final subsidence following the major eruptions. The evidence of the caldera collapse is that great thicknesses of Gwangju porphyritic granite erupted through ring fractures rather than central vents.
Weathering of caldera rim tuffs remained columnar joints of colonnades, which are currently the colonnades in Mt. Mudeung, because welded tuffs in the caldera tend to be more resistant to erosion than sedimentary tuffs outside the caldera rim.

\section{Discussion and conclusion}

Our study indicates that the elevation-dependent distribution of columnar joints of colonnades in Mt. Mudeung was established by discontinuous tuff emplacements and simultaneous development of columnar joints in these tuff emplacements. 
First, the geochemical and chronological studies were conducted using whole-rock samples obtained from the Seoseok-dae, Ipseok-dae, Gwangseok-dae, and Chotdaebong colonnades. The results show that columnar joints of the colonnades in Mt. Mudeung formed in the Late Cretaceous and that the magmas were calc-alkaline, with compositions ranging from andesitic to dacitic tuffs and pyroclastics. The similar geochemistry of the different lithological units, together with their volcanic formation, as evident from calc-alkaline trends in the AFM diagram, supports a co-magmatic origin for the tuff emplacements as a typical arc volcano. Accordingly, we propose that geochemical characteristics of the Mudeungsan Tuff indicate that the magma generating the tuff formed via subductionrelated magmatism with crustal assimilation, which implies that the volcanism occurred in the volcanic arc that resulted from subduction of the Izanagi Plate along the southern margin of the Korean Peninsula. However, there are no distinct geochemical differences among whole-rock samples; all of the tuffs originated from the one magma chamber.

Second, the U-Pb geochronology of zircons indicate that all colonnades were established $\sim 85 \mathrm{Ma}$, except for the Chotdae-bong colonnades, which are dated to $\sim 87 \mathrm{Ma}$. Scaling analysis and numerical calculations suggest a promising interpretation for the genesis of the columnar joints of the colonnades: three large explosive andesitic-dacitic eruptions lead to emplacement, cooling and welding of the Mudeungsan Tuff and the creation of large columnar joints in MMNG. The modeling suggests that the key feature of the formation of columnar joints in the welded tuff is related to the collapse of the welded tuff into the emptied magma chamber and the weathering of the circumferential rim tuff.

Third, the Chotdae-bong colonnades are approximately 2 million years older than the other colonnades are, which poses a problem for the simple interpretation of successive tuff emplacements in MMNG. There should be a discontinuity at the Baekma ridge between Jangbul-jae (JBJ) and Mt. Anyang (A), but no distinct discontinuity has been observed. Additionally, the absolute age of the Mudeungsan Tuff in the summit area (48.1 $\pm 1.7 \mathrm{Ma}$ from Ahn (2010)) is much younger than the ages $(\sim 85 \mathrm{Ma})$ of the underlying colonnades (determined in this study), including the Seoseok-dae, Ipseok-dae, and Gwangseok-dae colonnades. This implies another discontinuity between the $C_{1 L}$ and $\mathrm{C}_{2 \mathrm{U}}$ groups of colonnades (see Fig. 10 for definitions of the groups), but no such discontinuity has not been observed clearly. In addition, the absolute ages of the Sinseon-dae colonnades, as the lowest columnar joints, were not evaluated because of the significant weathering of the colonnades and the paucity of rock samples. To resolve these issues, detailed field works designed for evaluating potential discontinuities or absolute age dating of the colonnades at the summit area (Sinseon-dae and Jung-bong) should be required.
Fourth, striae, typical linear structures on a column face created by discontinuous cooling of the tuff emplacement, are observed only in the northern Seoseok-dae colonnades. Because water infiltration along columnar joints continuously removes heats, the discontinuous growth of columnar joints might not be developed, as assumed in our numerical experiments. It is also possible that weathering removed the striae from the column faces.

Fifth, we only obtained limited data of the face widths for a scaling analysis because of rare intact colonnades that have not experienced significant weathering and fracturing. However, to further test our hypothesis of the three-stage emplacements of the Mudeungsan Tuff, additional data measurements of the face widths throughout the colonnades should be required. Furthermore, the simplified numerical models used in this study only approximate the growth rate of columnar joints, which are reasonable for the scaling analysis (Fig. 9). Although we assumed that the growth rate of the columnar joints in the early stage represents the effective growth rate, this assumption requires additional, effective cooling processes such as water infiltration along the joints, which is discussed in previous studies (Goehring et al., 2009; Grossenbacher and McDuffie, 1995). If there is continuous water infiltration, the growth rate of columnar joints might remain constant with time. Future work of numerical modeling should test the effect of water infiltration on jointing growth. Although laboratory experiments are not relevant to the development of entablatures, the existence of an entablature between the $C_{2 U}$ and $C_{2 L}$ colonnades should be verified.

\section{Additional files}

Additional file 1: Table S1. U-Th-Pb isotopic results for zircon.

Additional file 2: Figure S1. a) Columnar joints of the Jiwang-bong colonnades. b) Jigong neodeol (talus in Korean) distributed in the southern Mt. Mudeung. Figure S2. a and b) Columnar joints of the Seoseok-dae (SS) colonnades. c) The striae developed in the column face which are observed in the northern Seoseok-dae. The ruler is approximately $30 \mathrm{~cm}$ long. Figure S3. a) Columnar joints of the Ipseokdae (IS) colonnades. b and c) Riedel shear-like fractures developed in some colonnades. d) Ipseok-dae colonnades of which face widths are relatively small, called small-scale colonnades. The person in the picture is approximately $170 \mathrm{~cm}$ tall. Figure $\mathbf{S 4}$. $\mathrm{a}$ and b) columnar joints of the Gwangseok-dae (GS) colonnades which are the largest colonnades in Mt. Mudeung area. The person in the picture is approximately $170 \mathrm{~cm}$ tall. c) Measurement of diameters and face widths, the largest values observed in Mt. Mudeung area; The maximum face width of colonnades is approximately $9 \mathrm{~m}$. Figure S5. a) Columnar joints of the Sinseon-dae (SSD) colonnades. b) Map view of a cross-section of a colonnade which shows pentagonal shape with secondary fractures by weathering. The hammer is approximately $25 \mathrm{~cm}$ long. Figure S6. a and b) Columnar joints of the Chotdae-bong colonnades. (c) Map view of a crosssection of a colonnade which shows hexagonal shape with secondary fractures by weathering. The cellphone is approximately $15 \mathrm{~cm}$ long. Figure S7. a) Columnar joints of the colonnade by the trail between the Ipseok-dae and Gwangseok-dae colonnades (b) Two massive colonnades near the Heliport, Buk-bong (B). c) Face widths of a colonnade at the Gate of Air force facility ( $H$ in Figure 10$)$. 


\section{Competing interests}

The authors declare that they have no competing interests.

\section{Authors' contributions}

$\mathrm{CL}$ (first author) gained rock samples, conducted geochemical/petrological experiments and wrote the manuscript. MH gained rock samples and gave advice about general preparation of the manuscript. KY conducted the absolute age dating of the rock samples. CL (corresponding author) gained rocks samples, conducted numerical experiments and scale analysis, and supervised manuscript preparation. All authors read and approved the final manuscript.

\section{Acknowledgements}

We thank two anonymous reviewers for their careful reviews, which significantly improved our manuscript. We also thank Dr. Nobuo Geshi for his editorship. This study is supported by the National Research Foundation of Korea Grant funded by the Ministry of Education, Science and Technology of Korea Government (NRF-35B-2011-1-C00043).

\section{Author details}

${ }^{1}$ Faculty of Earth and Environmental Sciences, Chonnam National University, Gwangju 500-757, Republic of Korea. ${ }^{2}$ Korea Basic Science Institute, Ochang, Cheongwon, Chungbuk 363-883, Republic of Korea.

Received: 29 April 2015 Accepted: 2 September 2015

Published online: 15 September 2015

\section{References}

Ahn KS (2010) Geology and landscape of Mt. Mudeung Province Park, Korea. J Petrological Soc Korea 19:109-121

Cha MS, Yun SH (1988) Cretaceous volcanic cauldrons and ring complexes in Korea. J Geol Soc Korea 24:67-86

Gill J (1981) Orogenic andesites and plate tectonics. Springer, Berlin

Goehring L, Mahadevan L, Morris SW (2009) Nonequilibrium scale selection mechanism for columnar jointing. Proc Natl Acad Sci 106:387-392

Grossenbacher KA, McDuffie SM (1995) Conductive cooling of lava: columnar joint diameter and stria width as functions of cooling rate and thermal gradient. J Volcanol Geotherm Res 69:95-103

Hoskin PWO, Black LP (2000) Metamorphic zircon formation by solid-state recrystallization of protolith igneous zircon. J Metamorph Geol 18:423-439

Irvine TN, Baragar WRA (1971) A guide to the chemical classification of the common volcanic rocks. Can J Earth Sci 8:523-548

Jung W, Kil Y, Huh M (2014) A petrological study of the Mudeungsan Tuff focused on Heonwangbong and Anyangsan. J Petrological Soc Korea 23:325-336

Kim YJ, Lee CS (1988) The study on igneous rocks and their igneous activity in the Jangsoo-Unbong Area. J Geol Soc Korea 24:111-131

Kim YJ, Oh MS, Park JB (1993) Petrochemical study on the Kwangju granite body. Econ Environ Geol 26:83-96

Kim YJ, Park JB, Park BK (2002) Petrochemistry on igneous rocks in the Mt Mudeung area. J Petrological Soc Korea 11:214-233

Koh JS, Yun SH, Hong HC (2005) Morphology and petrology of Jisagae columnar joint on the Daepodong basalt in Jeju Island, Korea. J Petrological Soc Korea 14:212-225

Le Bas MJ, Maitre RWL, Streckeisen A, Zanettin B, Rocks I.S.o.t.S.o.I (1986) A chemical classification of volcanic rocks based on the total alkali-silica diagram. J Petrol 27:745-750

Lodge RWD, Lescinsky DT (2009a) Anisotropic stress accumulation in cooling lava flows and resulting fracture patterns: Insights from starch-water desiccation experiments. J Volcanol Geotherm Res 185:323-336

Lodge RWD, Lescinsky DT (2009b) Fracture patterns at lava-ice contacts on Kokostick Butte, OR, and Mazama Ridge, Mount Rainier, WA: Implications for flow emplacement and cooling histories. J Volcanol Geotherm Res 185:298-310

McDonough WF, Sun SS (1995) The composition of the Earth. Chem Geol 120:223-253

Park BK, Kim YJ, Kim YJ (2005) A minerlogical study of plagioclase in volcanic rocks from the Mt. Mudeung Area. J Mineralogical Soc Korea 18:155-164

Pearce JA (1982) Trace element characteristics of lavas from destructive plate boundaries. In: Thorpe RS (ed) Orogenic andesites and related rocks. John Wiley and Sons, Chichester, pp 528-548
Peck DL, Minakami T (1968) The formation of columnar joints in the upper part of Kilauean Lava Lakes, Hawaii. Geol Soc Am Bull 79:1151-1166

Sagong H, Kwon ST, Ree JH (2005) Mesozoic episodic magmatism in South Korea and its tectonic implication. Tectonics 24, TC5002

Spry A (1962) The origin of columnar jointing, particularly in basalt flows. J Geol Soc Aust 8:191-216

Steiger RH, Jäger $E$ (1977) Subcommission on geochronology: convention on the use of decay constants in geo- and cosmochronology. Earth Planet Sci Lett 36:359-362

Turcotte D, Schubert G (2002) Geodynamics, 2nd edn. Cambridge Univ. Press, Cambridge

Williams HM, Nielsen SG, Renac C, Griffin WL, O'Reilly SY, McCammon CA, Pearson N, Viljoen F, Alt JC, Halliday AN (2009) Fractionation of oxygen and iron isotopes by partial melting processes: Implications for the interpretation of stable isotope signatures in mafic rocks. Earth Planet Sci Lett 283:156-166

Won CK, Lee MW, Kim KH, Hong YK, Woo JG, Lee JM (1990) The study on cretaceous volcanism in the Sunchang Trough-compare study between Kyeongsan Basin Sunchang Trough and Inner-zone of S-W Japan. J Geol Soc Korea 26:165-184 